Article

\title{
Factors Governing Total and Permanganate Oxidizable C Pools in Agricultural Soils from Southern Italy
}

\author{
Giuseppe Badagliacca * (1), Maurizio Romeo, Emilio Lo Presti, Antonio Gelsomino and \\ Michele Monti * \\ Dipartimento di Agraria, Università degli Studi Mediterranea di Reggio Calabria, 89124 Reggio Calabria, Italy; \\ maurizio.romeo@unirc.it (M.R.); emilio.lopresti@unirc.it (E.L.P.); agelsomino@unirc.it (A.G.) \\ * Correspondence: giuseppe.badagliacca@unirc.it (G.B.); montim@unirc.it (M.M.)
}

Received: 19 February 2020; Accepted: 23 March 2020; Published: 1 April 2020

\begin{abstract}
The present investigation was aimed to quantify the three principal components of the soil carbon (C) stock, namely inorganic, organic and permanganate oxidizable, in $0-5 \mathrm{~cm}$ and $5-30 \mathrm{~cm}$ soil layers, of the main Mediterranean agricultural land coverages: olive grove, olive forest, citrus grove, vineyard, arable irrigated, arable rainfed and natural soil covered by Mediterranean scrub and garrigue. We assessed the contribution of soil properties and climatic variables on soil TOC and POxC by Pearson's correlations, multiple linear regressions, principal component analyses and variance partitioning. NAT and both olive cropping systems showed the highest TOC concentration while the other land covers showed values ranging between 8.0 and $26.6 \mathrm{~g} \mathrm{~kg}^{-1}$. Soil POxC represented between $0.5 \%$ and $2.2 \%$ of the total soil C. A large number of interrelated factors govern soil C accumulation in Mediterranean agroecosystems. Rainfall and temperature had a selective effect on soil $\mathrm{C}$ distribution between the sampling areas, while among soil properties, texture exerted a prominent effect, resulting in positive effects from clay and negative effects from sand. Soil POxC concentration showed a similar trend to soil TOC in all land uses although on each of them represent a different TOC portion.
\end{abstract}

Keywords: soil carbon stock; soil carbon assessment; labile organic carbon; land use; Mediterranean agroecosystems

\section{Introduction}

Soils contain the largest C stock on Earth, storing about $2500 \mathrm{Gt}$ of C in the first meter of depth, greater than the atmospheric and vegetation pools [1], with a fundamental role on global $\mathrm{C}$ cycle being a determining factor of soil ecosystem services such as biological, physical and chemical functions [2]. Therefore, even minimal variation of this large reserve can cause massive consequences on the biosphere from the fertility of the soil up to the greenhouse gases concentration in the atmosphere [3]. Soil $\mathrm{C}$ stock is generally constituted by two components, both involved in the $C$ exchanges between soil and atmosphere: an inorganic (TIC) and an organic (TOC) C pool. If the TIC pool strictly depends on the parent material and soil forming factors, representing the most stable component, on the other side, the TOC pool, which is more labile, is influenced by several biotic and abiotic factors. Therefore, for its considerable importance, it is fundamental to understand the factors that can influence the $\mathrm{C}$ stock in the soil $[4,5]$. The relationship between TOC and biotic and abiotic factors can strongly vary across environments and is affected by land use and vegetation types, making it possible to identify specific factors that govern soil $\mathrm{C}$ accumulation in the agroecosystems at a regional scale (arable, natural and semi-natural) [5,6]. Among biotic factors there are vegetation type, crop residue deposition and the soil microbial community $[7,8]$, while abiotic factors include topography, soil physicochemical 
properties [9] and climate [10]. Southern Italy is a Mediterranean region where the agricultural activity is characterized by a high spatial variability, both in the type and intensity with which it is practiced, generally on soil with an organic $C$ concentration below the critical threshold of $2 \%$ [11] and considered with a high vulnerability to global climate change and desertification risk [12]. With regard to TIC, it is present in variable shares predominantly due to calcareous soil parent material [13], while carbonates represent in many cases the dominant form of $C$ in soil [14] resulting from dissolution and precipitation processes under xeric climatic conditions [15]. Therefore, quantifying both those $C$ pools in Mediterranean soils is crucial to assessing the effects of management and land use as well as of climate [16]. Among soil organic C pools, studying the readily available and easily degradable forms can provide knowledge about the soil $C$ dynamics and sequestration, allowing the future level of $C$ stock under different environments to be predicted, representing an early and sensitive soil quality indicator [17]. Indeed, litter-derived biomolecules such as polysaccharides, lipids and proteins are quickly decomposable and rapidly supply soil food, also interacting, with soil microbiota [18]. Therefore, in addition to studying TOC variation that has long term variability, information related to this pool can help us to understand land management effects, even in the short term. The aims of this study are (a) to investigate the variability of TIC, TOC, POxC and C stocks in the typical agroecosystems of the Calabria region in order to provide baseline information at the regional scale; (b) to assess the effects of soil and climate parameters affecting TOC and POxC across agroecosystems, explaining their effects; and (c) to examine relative weight of land use, climate and soil properties in determining TOC and POxC levels in the soils of Calabria.

\section{Materials and Methods}

\subsection{Study Area}

The Calabria region is located at the southern end of the Italian peninsula and is bounded by the Tyrrhenian Sea on the western side and by the Ionian Sea on the southern and eastern sides. Most of the territory is mountainous and hilly; only $9 \%$ is represented by the plains. Agricultural areas include arable lands, tree crops, permanent meadows and pastures covering $28.7 \%, 45.7 \%$ and $25.6 \%$, respectively. The main herbaceous crops are cereals, pulses and forage legumes and vegetable crops. Among the orchards, olive groves, vineyards, citrus and fruit trees are cultivated [19]. The main part of Calabria is characterized by a typically Mediterranean climate (Csa-Hot-summer Mediterranean climate) in Köppen's (1948) classification, with dry and hot summers and low average temperatures [20]. In Calabria, an average yearly rainfall of $1150 \mathrm{~mm}$ corresponds to noticeable seasonal contrasts and to high intraregional variability. Temperatures, generally along the coasts, never fall below $10{ }^{\circ} \mathrm{C}$ and never rise above $40^{\circ} \mathrm{C}$, but in the internal areas during the summer the maximum temperatures reach $42-44{ }^{\circ} \mathrm{C}$. Because of its geographical location, topography and relief-with mountain ranges perpendicular to the direction of the main wet currents-Calabria is affected by rains highly variable in both time and space. The eastern side of the region is less rainy than the west side, especially as the precipitations come frequently from the west and discharge some of their rain on the Sila Plateau whilst moving towards the east. The Western coastal relief and the Serre relief receive more rainfall than the Sila Plateau, which is partially shielded from the first mountain range (Figure 1). Yearly average precipitation is $>2000 \mathrm{~mm}$ on the Western Coastal relief and the Aspromonte Massif, whereas precipitation on the Ionian mountain slopes is $600-1000 \mathrm{~mm}$, with values of $\sim 500 \mathrm{~mm}$ along the coastal plains. With regards to annual maxima of high-intensity and short-duration rainfall, three homogeneous rainfall regions were delimited in Calabria, including (i) a Tyrrhenian region ( $25.8 \%$ of the region) along the western Tyrrhenian coast, (ii) a Central region (44.3\%), comprising the mountain ranges along the main divide and (iii) an Ionian region along the eastern Ionian coast $(29.9 \%)$. The Tyrrhenian rainfall region is characterized by more frequent and less severe rainfall events than the Ionian rainfall region, whereas the Central rainfall region has events with intermediate characteristics. Seasonality of the rainfall regime in Calabria is characterized by abundant rains occurring in autumn 
and winter along the Tyrrhenian slopes (more than $70 \%$ of yearly total precipitation falls from October to March) and more heavily on the Ionian side. In the inland mountainous areas, from the Pollino to the Sila down to the Aspromonte, the climate is continental cold with hard and snowy winters and mild and quite rainy summers [20]. The internal central zone, which extends along the alluvial plains of the Crati and Mesina rivers, is characterized by climatic features intermediate compared to the previous ones. The Calabrian arch is part of an European-vergent chain characterized by an extensional tectonic, which is still active. Calabrian soils are highly heterogeneous and the prevailing soil orders are the following: Andisol, Vertisol, Alfisol, Inceptisol and Entisol [21,22]. A detailed description of soil properties is available in ARSSA [22].

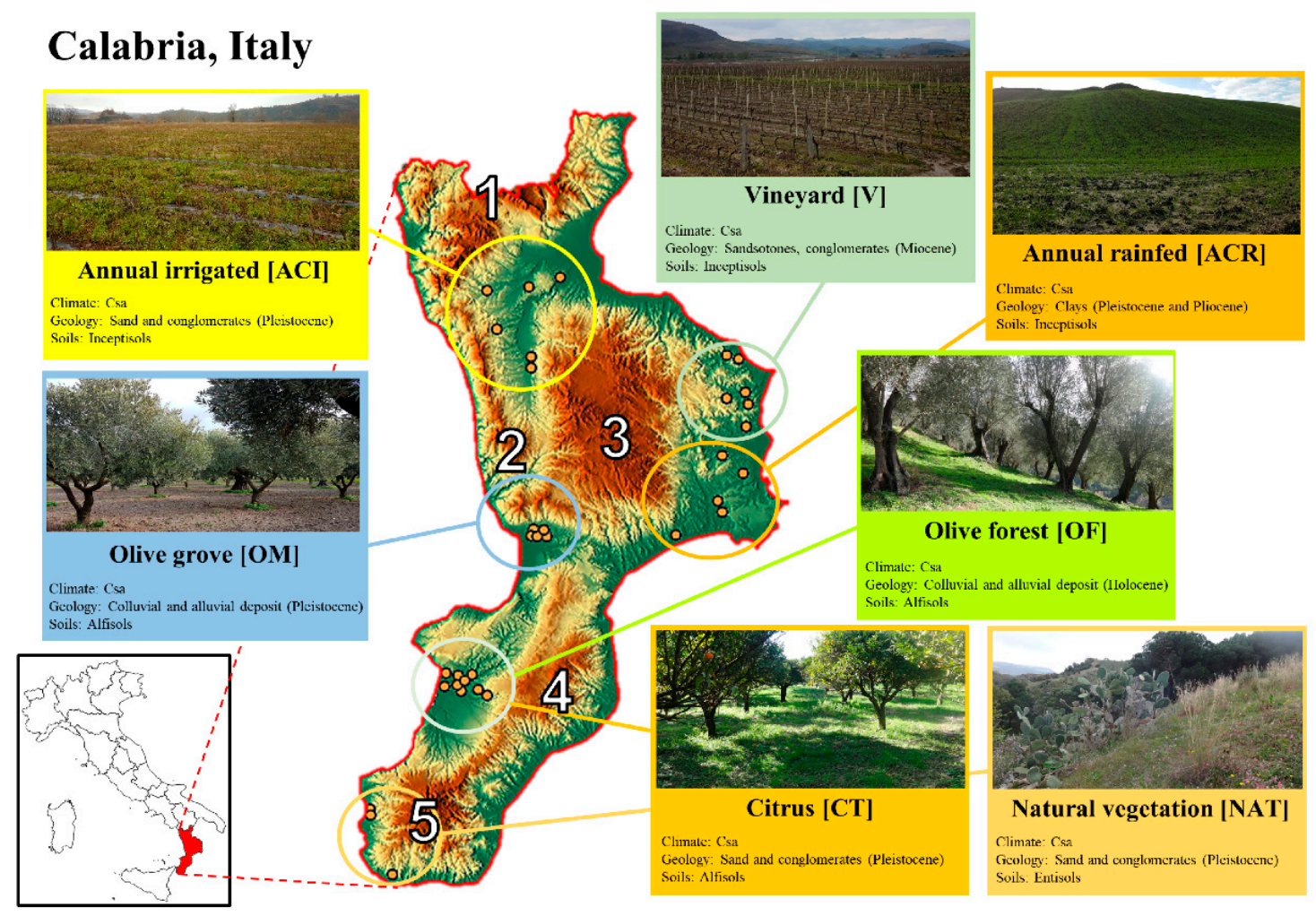

Figure 1. Location and main properties of the study sites. Climate indication according to Köppen classification, while soil classification was retrieved from ARSSA [22]. Numbers indicate the principal mountainous areas of Calabria; 1: Pollino Massif; 2: Western Coastal relief; 3: Sila Plateau; 4: Serre relief; 5: Aspromonte relief.

\subsection{Sampling Sites}

Soil samples were collected from the main agricultural land uses diffused in the Calabrian region and from one natural area: olive grove (OM) (modern olive cultivation characterized by medium size plants); olive forest (OF) (traditional olive cultivation characterized by medium large size plants); citrus grove (CT); vineyard (V); arable irrigated cropping systems (ACI); arable rainfed cropping system (ACR); natural undisturbed soil covered by Mediterranean scrub and garrigue (NAT).

Soil samples were collected from sites with an unchanged land use during the last 25-30 years assuming that main soil variables, including $C$ stocks, have already reached an equilibrium state. The sampling sites were chosen after an extensive spatial-temporal analysis of satellite images (from 1980) and soil maps [22]. The location of the study areas, their main properties and the sampling point distribution are presented in Figure 1. 


\subsection{Soil Sampling}

For each of the 7 land uses considered, 6 typical and representative areas, characterized by a long-term land use, were chosen, and within each area 5 points were elected for sampling. As much as possible, the sampling points within each area were selected very carefully in order to well represent the land use investigated. At each sampling point, a sampling area was identified and 3 subsamples were taken from $0-5 \mathrm{~cm}(\mathrm{~A})$ and from 5-30 $\mathrm{cm}$ (B) soil layers by a manual auger and then thoroughly mixed to form a composite sample. Only the mineral soil was sampled after removing the superficial litter and organic material. Soil bulk density (BD) was determined by the core method [23]. Soil sampling was carried out in spring 2017. The total number of collected soil samples was 420 (Figure 1).

\subsection{Sample Preparation and Analysis}

After sampling, soils were transferred to the lab, air-dried and divided in two aliquots; one was sieved to pass through a $2 \mathrm{~mm}$ sieve whereas the other one was crushed to pass through a $500 \mu \mathrm{m}$ sieve. Both aliquots were stored at room temperature until further analysis. Soil sieved with the $2 \mathrm{~mm}$ sieve was used to determine soil $\mathrm{pH}$, electrical conductivity (EC), particle size distribution (PSD) and permanganate oxidizable $\mathrm{C}$ (POxC), while the aliquot sieved with the $500 \mu \mathrm{m}$ sieve was used for inorganic $\mathrm{C}\left(\mathrm{C}-\mathrm{CaCO}_{3} ; \mathrm{TIC}\right)$, total organic $\mathrm{C}$ (TOC) and $\mathrm{N}$ (TN). Soil $\mathrm{pH}$ was measured in a 1:2.5 (w/v) suspension of soil in a $0.01 \mathrm{M}$ calcium chloride solution, whereas soil EC was measured in a 1:2 (w/v) suspension of soil in water, in accordance with Sparks [24]. TIC (total soil C-CaCO 3 ) was determined by a gas-volumetric method using a Dietrich-Fruhling calcimeter as described in Sparks [24]. TOC and TN were determined by the dry combustion method using an elemental analyzer LECO CN628 (LECO Corporation, St Joseph, MI, USA). Soil POxC was determined according to the method developed by Weil et al. [25] and Culman et al. [26]. Briefly, $2.5 \mathrm{~g}$ of air-dried soil were weighed into $50-\mathrm{mL}$ screw-top centrifuge tubes. To each tube, $18 \mathrm{~mL}$ of deionized water and $2 \mathrm{~mL}$ of $0.2 \mathrm{M} \mathrm{KMnO}_{4}$ solution (prepared in $1 \mathrm{M} \mathrm{CaCl}_{2}$ ) were added, and tubes were vigorously hand-shaken for $2 \mathrm{~s}$ and then mechanically shaken at $240 \mathrm{rpm}$ for $2 \mathrm{~min}$ using a horizontal shaker. Tubes were removed from the shaker and allowed to settle at room temperature for exactly $10 \mathrm{~min}$. After $10 \mathrm{~min}, 0.5 \mathrm{~mL}$ of the supernatant were transferred into a second $50-\mathrm{mL}$ centrifuge tube and mixed with $49.5 \mathrm{~mL}$ of deionized water. Finally, sample absorbance was read at $550 \mathrm{~nm}$ with a UV/Vis Lambda 25 (PerkinElmer, Norwalk, CT, USA) spectrophotometer using UV WinLab Software (PerkinElmer). The amount of non-labile $\mathrm{C}(\mathrm{NLC})$, not oxidized by $\mathrm{KMnO}_{4}$, was determined as the difference between TOC and POxC [27]. Particle size distribution (PSD) was determined using an Analysette 22 MicroTec Plus (Fritsch GmbH, Markt Einersheim, Germany) laser particle sizer following the standard procedure by Walling and Collins [28]. Fourteen soil particle size classes were determined (0.9-1.4-3.3-6.0-8.1-12.1-19.9-29.6-72.4-107.8-263.7-433.4-869.0-2000.0 $\mu \mathrm{m})$. Clay, silt and sand percentages were determined according to the USDA classification. Soil C stocks were calculated by the following equation [29]:

$$
\mathrm{C} \text { stock }=\mathrm{TOC} \times \mathrm{BD} \times \mathrm{D}
$$

where $C$ stock is the organic $C$ stock of the investigated soil layer $\left(\mathrm{Mg} \mathrm{ha}^{-1}\right)$, TOC is the concentration of TOC in the soil (\%), BD is the soil bulk density $\left(\mathrm{g} \mathrm{cm}^{-3}\right)$ and $\mathrm{D}$ is the soil layer thickness $(\mathrm{cm})$.

\subsection{Climatic Data}

Climatic and bioclimatic data were provided from Worldclim [30] and from CGIAR-CSI [31,32] with a spatial resolution of $30 \mathrm{~s}\left(\sim 1 \mathrm{~km}^{2}\right)$. Data used were the monthly and yearly averages from the period 1950-2000. 


\subsection{Data Calculation and Statistical Analyses}

The main statistical index (mean and standard deviation) were calculated to describe each soil property involved in the TOC dynamics. Data were tested for deviation from normality (Kolmogorov-Smirnov test) and homogeneity of within-group variances (Levene's test). Statistical analysis among agroecosystems was performed in the SAS v9.2 environment (SAS inst., 2009) (proc MIXED) for soil carbon pools (TIC, TOC, POxC, NLC and C stock,). Duncan's test at $p<0.05$ was used for pairwise multiple comparison between means. In order to study the relationship between the two soil layers ( $0-5$ and 5-30 cm), TOC concentration linear regression analyses were performed in MS Excel. With the purpose of distinguishing the contribution of soil and bioclimatic factors to TOC and POxC concentrations, Pearson correlation coefficient (proc corr) and stepwise multiple linear regression (proc reg) were carried out in the SAS v9.2 environment [33], while principal component analysis (PCA) and variance partitioning (varpart) were performed using R v3.5.0 statistical software [34] with FactoMineR v1.41 [35] and vegan package v2.5-2 [36]. Pearson's correlation coefficients between soil TOC and POxC concentrations in the $0-5$ and $5-30 \mathrm{~cm}$ soil layers and 27 soil, climatic and bioclimatic variables were calculated in order to study the relationships between the soil $\mathrm{C}$ stable or labile pool and pedoclimatic and bioclimatic variables. Stepwise regression analysis was used to analyze the relationship between soil TOC and POxC concentration in $0-5$ and 5-30 cm soil layers and the 27 soil, climatic and bioclimatic properties. In particular, a dataset from each $\mathrm{C}$ pool and soil layer was randomly separated (500 bootstrap resampling interactions) into a training set $(70 \%)$, used to derive the model, and an independent validation set $(30 \%)$, to validate the model. The process was guided to achieve the maximum $\mathrm{R}^{2}$ values and an F probability of 0.05 was set for include or remove variables. Principal component analysis (PCA) was performed using data of the 27 soil, climatic and bioclimatic variables to establish the importance of each property in determining TOC and POxC concentration among the agroecosystems. Principal component means (centroid values) were calculated for each ecosystem and the significance between means was determined using Mahalanobis distance. The relative influence of soil, land use and climate on soil TOC and POxC concentrations was assessed by using a variance partitioning. The variance partitioning was based on partial redundancy analysis (pRDA), which allows one to predict the percentage contributions of each variable (soil, land use, climate) to the total variance of the studied variables (TOC and POxC). The pRDA results consisted of variation attributed exclusively to one of the studied variables (soil, land use, climate), shared variation explained (interaction among variables) and residual variation, which is the non-explained variation by the considered factors. The statistical significance effect of each group of variables was tested by means of one-way ANOVA.

\section{Results}

\subsection{Soil Properties}

On the upper soil layer $(0-5 \mathrm{~cm})$, total nitrogen ranged from $1.0 \mathrm{~g} \mathrm{~kg}^{-1}$ to $2.5 \mathrm{~g} \mathrm{~kg}^{-1}$ with the lowest values observed in ACI and the highest in NAT soils (Table 1).

Soil $\mathrm{pH}$ showed marked differences between sites reflecting soil parental material and climate conditions, ranging from acid (5.3) to neutral (7.5) conditions. The lowest values were observed on both olive cultivations (OM and $\mathrm{OF}$ ), while the highest were detected on arable cropping system (ACI and $\mathrm{ACR}$ ) and vineyard (V). Intermediate $\mathrm{pH}$ levels were under CT (6.8) and NAT (6.3) land cover (Table 1). Soil electrical conductivity (EC) varied from 151 to $293 \mu \mathrm{S} \mathrm{cm}^{-1}$ with the higher values in OM and NAT, which showed high variability among the sampling points. With regard to the deeper soil layer $(5-30 \mathrm{~cm})$, soil TN ranged from 0.8 to $1.7 \mathrm{~g} \mathrm{~kg}^{-1}$, showing large differences from the superficial soil layer on both olive sites $(-1 \%$ in OM and $-0.9 \%$ in OF) and under NAT land cover $(-1.5 \%)$ (Table 1$)$. Soil BD, among the two sampled soil layers, ranged from 0.92 and $1.17 \mathrm{~g} \mathrm{~cm}^{-3}$ with the lowest values observed in OF and the highest in CT treatment. In general, higher values $(+5.0 \%$, on average) were observed in the deep soil layer $(5-30 \mathrm{~cm})$ than in the superficial ones $(0-5 \mathrm{~cm})$. 
Table 1. Main soil properties of $0-5 \mathrm{~cm}$ and $5-30 \mathrm{~cm}$ soil layers at the experimental sites. OM: olive grove; OF: olive forest; ACI: arable crop irrigated; ACR: arable crop rainfed; V: vineyard; CT: citrus; NAT: Mediterranean scrub and garrigue. Data reported are mean $(\mu)$ and standard deviation $(\sigma)(n=30)$.

\begin{tabular}{|c|c|c|c|c|c|c|c|c|}
\hline \multicolumn{9}{|c|}{ 0-5 cm Soil Layer } \\
\hline \multirow{2}{*}{ Land Use } & \multicolumn{2}{|c|}{$\mathrm{TN}\left(\mathrm{g} \mathrm{kg}^{-1}\right)$} & \multicolumn{2}{|c|}{ pH (-) } & \multicolumn{2}{|c|}{$\mathrm{EC}\left(\mu \mathrm{S} \mathrm{cm}^{-1}\right)$} & \multicolumn{2}{|c|}{$\mathrm{BD}\left(\mathrm{g} \mathrm{cm}^{-3}\right)$} \\
\hline & $\mu$ & $\sigma$ & $\mu$ & $\sigma$ & $\mu$ & $\sigma$ & $\mu$ & $\sigma$ \\
\hline $\mathrm{OM}$ & 2.3 & 0.4 & 5.7 & 0.6 & 293 & 174 & 1.01 & 0.05 \\
\hline $\mathrm{OF}$ & 2.5 & 0.4 & 5.3 & 0.5 & 151 & 72 & 0.92 & 0.02 \\
\hline $\mathrm{ACI}$ & 1.0 & 0.1 & 7.2 & 0.4 & 255 & 61 & 1.13 & 0.08 \\
\hline ACR & 1.2 & 0.2 & 7.5 & 0.1 & 229 & 54 & 1.02 & 0.07 \\
\hline $\mathrm{V}$ & 1.2 & 0.1 & 7.4 & 0.1 & 272 & 59 & 1.08 & 0.06 \\
\hline $\mathrm{CT}$ & 1.5 & 0.2 & 6.8 & 0.7 & 236 & 81 & 1.17 & 0.08 \\
\hline NAT & 2.5 & 0.7 & 6.3 & 0.8 & 279 & 128 & 1.01 & 0.10 \\
\hline \multicolumn{9}{|c|}{ 5-30 cm Soil Layer } \\
\hline $\mathrm{OM}$ & 1.4 & 0.3 & 5.7 & 0.7 & 166 & 91 & 1.11 & 0.03 \\
\hline $\mathrm{OF}$ & 1.7 & 0.4 & 5.0 & 0.5 & 105 & 77 & 1.03 & 0.02 \\
\hline $\mathrm{ACI}$ & 0.8 & 0.1 & 7.2 & 0.5 & 191 & 51 & 1.16 & 0.09 \\
\hline ACR & 1.1 & 0.1 & 7.5 & 0.1 & 223 & 38 & 1.04 & 0.05 \\
\hline $\mathrm{V}$ & 1.0 & 0.1 & 7.5 & 0.1 & 230 & 37 & 1.13 & 0.05 \\
\hline $\mathrm{CT}$ & 1.2 & 0.2 & 6.9 & 0.6 & 204 & 77 & 1.11 & 0.08 \\
\hline NAT & 1.0 & 0.2 & 6.2 & 1.1 & 186 & 99 & 1.14 & 0.09 \\
\hline
\end{tabular}

Particle size distribution, on average among both soil layers studied, showed values ranging from $2.0 \%$ to $28.9 \%$, from $51.7 \%$ to $75.9 \%$ and from $12.6 \%$ to $22.4 \%$, for sand, silt and clay, respectively. Soil texture varied from sandy-loam to silty-clay-loam (Table 2). The predominant textural class was silt-loam. Sand concentration was higher in NAT with respect to the other sampling sites, while lower values were registered in $\mathrm{ACI}, \mathrm{ACR}, \mathrm{V}$ and $\mathrm{CT}$ (Table 2).

Table 2. Distribution of soil particle sizes on the three main diametric classes (USDA) in the $0-30 \mathrm{~cm}$ soil layer for each land cover. OM: olive grove; OF: olive forest; ACI: arable crop irrigated; ACR: arable crop rainfed; V: vineyard; CT: citrus; NAT: Mediterranean scrub and garrigue. Data reported are mean $(\mu)$ and standard deviation $(\sigma)(n=30)$.

\begin{tabular}{ccccccc}
\hline \multirow{2}{*}{ Land Use } & \multicolumn{2}{c}{ Sand (\%) } & \multicolumn{2}{c}{ Silt (\%) } & \multicolumn{2}{c}{ Clay (\%) } \\
\cline { 2 - 7 } & $\boldsymbol{\mu}$ & $\boldsymbol{\sigma}$ & $\boldsymbol{\mu}$ & $\boldsymbol{\sigma}$ & $\boldsymbol{\mu}$ & $\boldsymbol{\sigma}$ \\
\hline OM & 17.7 & 17.5 & 63.4 & 16.6 & 18.9 & 5.7 \\
OF & 27.8 & 20.2 & 51.7 & 14.3 & 20.5 & 6.2 \\
ACI & 2.0 & 4.5 & 75.9 & 4.0 & 22.1 & 2.7 \\
ACR & 9.5 & 11.1 & 71.4 & 9.9 & 19.1 & 1.8 \\
V & 2.0 & 4.5 & 75.6 & 4.6 & 22.4 & 3.8 \\
CT & 10.5 & 14.4 & 72.9 & 12.5 & 16.6 & 3.4 \\
NAT & 28.9 & 19.1 & 58.4 & 13.2 & 12.6 & 8.2 \\
\hline
\end{tabular}

\subsection{Soil C}

Total soil C concentration ranged from 19.5 to $36.2 \mathrm{~g} \mathrm{~kg}^{-1}$ in the $0-5 \mathrm{~cm}$ soil layer and from 14.4 to $27.6 \mathrm{~g} \mathrm{~kg}^{-1}$ in the $5-30 \mathrm{~cm}$ soil layer (Figure 2). 

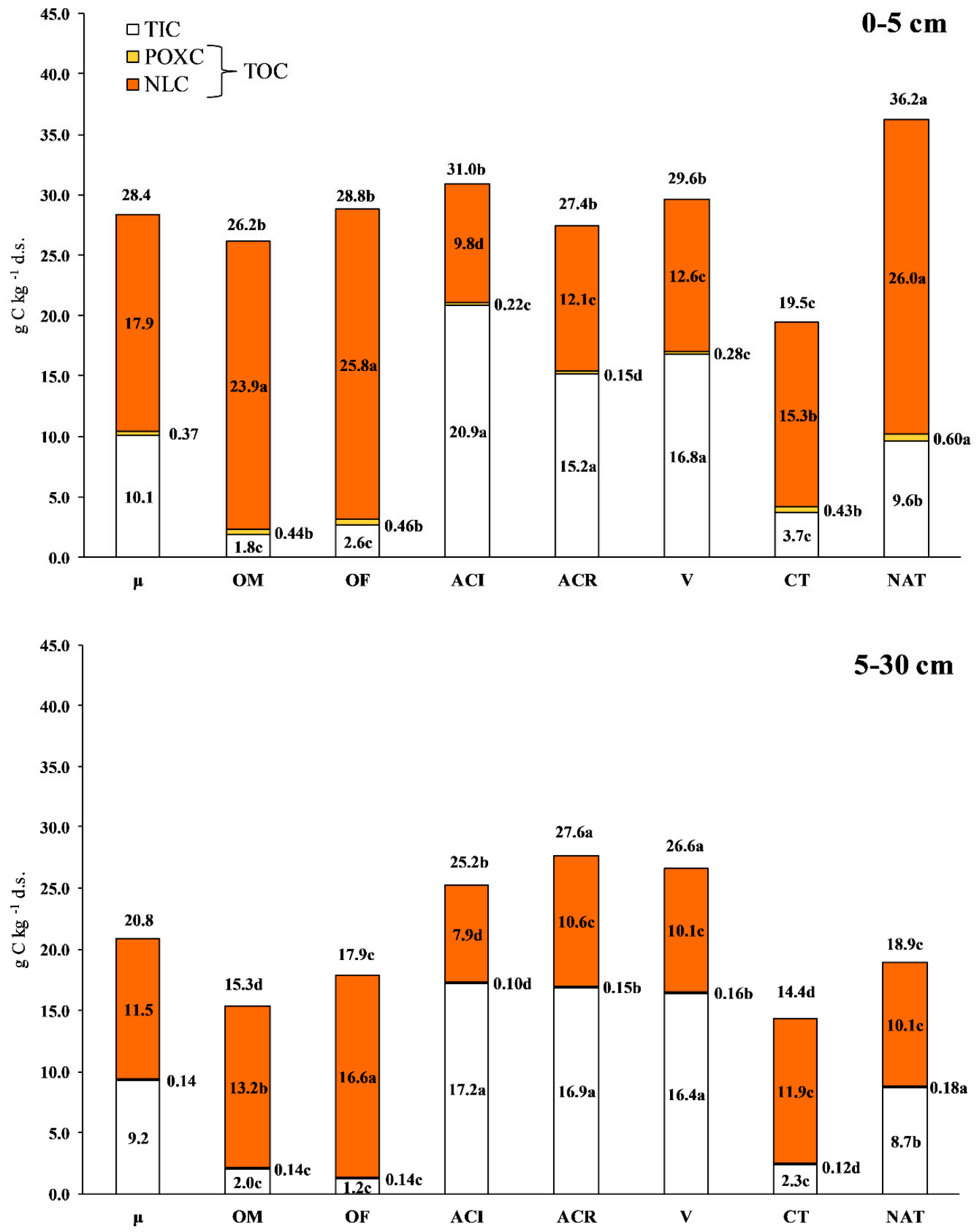

Figure 2. Total soil $\mathrm{C}$ concentration and $\mathrm{C}$ partitioning (TIC, POxC and NLC) under different land use at $0-5 \mathrm{~cm}$ soil layer and $5-30 \mathrm{~cm}$ soil layers; $0-5 \mathrm{~cm}$ and $5-30 \mathrm{~cm}$ soil layer average value $(\mu)$; OM: olive grove; OF: olive forest; ACI: arable crop irrigated; ACR: arable crop rainfed; V: vineyard; CT: citrus; NAT: Mediterranean scrub and garrigue. Reported values are means $(n=30)$. Different letters indicate significant differences among agroecosystems (Duncan's test at $p<0.05$ ).

In the superficial soil layer, the highest value was observed on NAT and the minimum on CT, while the other land uses showed values ranging between 26.2 and $31.0 \mathrm{~g} \mathrm{~kg}^{-1}$. In the $5-30 \mathrm{~cm}$ soil layer, the highest $\mathrm{C}$ concentration was observed in ACR while the lowest was also observed in CT (Figure 2). On average, in the $0-5 \mathrm{~cm}$ soil layer, TOC was higher by $+37 \%$ than in the $5-30 \mathrm{~cm}$ soil layer. Differences between the two soil layers were large in olive grove (OM and OF) and NAT and small 
in other land uses (Figure 2). In the $0-5 \mathrm{~cm}$ soil layer, soil TIC ranged from $1.8 \mathrm{~g} \mathrm{~kg}^{-1}$ to $20.9 \mathrm{~g} \mathrm{~kg}^{-1}$. The highest inorganic $C$ concentration was retrieved in $\mathrm{ACI}$, followed by ACR and V, while the lowest values were observed under olive, both $\mathrm{OM}$ and $\mathrm{OF}$, and $\mathrm{CT}$ (Figure 2). Intermediate values, around $10.0 \mathrm{~g} \mathrm{~kg}^{-1}$, were retrieved on NAT soils (Figure 2). In this soil layer, TIC represented from $7 \%$ to $67 \%$ of the total soil C (Figure 3).
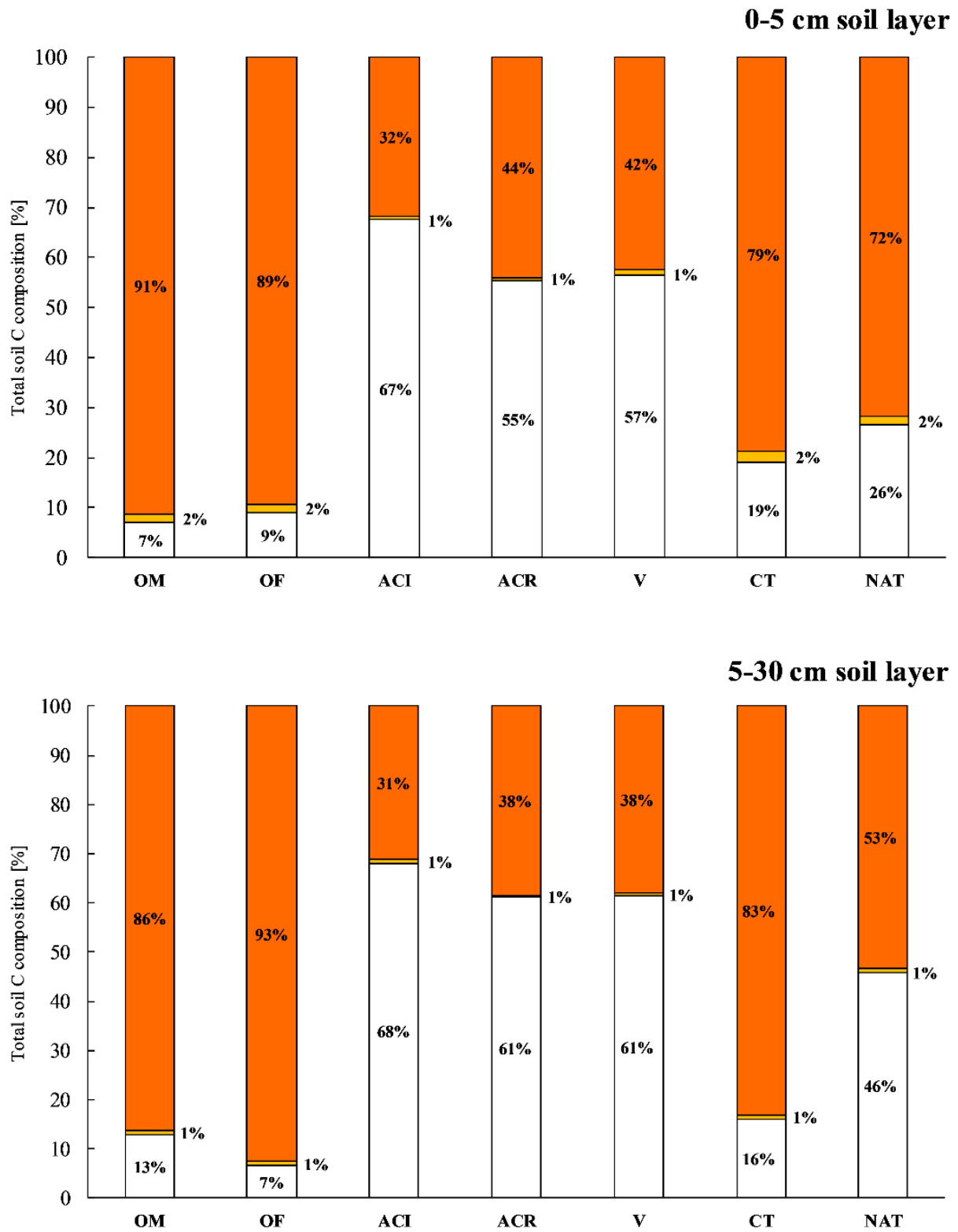

Figure 3. Total soil $\mathrm{C}$ compositional percentages under the different land uses at the $0-5 \mathrm{~cm}$ soil layer and 5-30 cm soil layer. OM: olive grove; OF: olive forest; ACI: arable crop irrigated; ACR: arable crop rainfed; V: vineyard; CT: citrus; NAT: Mediterranean scrub and garrigue. Reported values are means $(n=30)$.

Soil POxC, identified as the labile soil C, ranged from 0.15 to $0.60 \mathrm{~g} \mathrm{~kg}^{-1}$. Higher values of POxC were observed on NAT followed by olive sites (OM and OF; $\left.0.45 \mathrm{~g} \mathrm{~kg}^{-1}\right)$ and $\mathrm{CT}\left(0.43 \mathrm{~g} \mathrm{~kg}^{-1}\right)$, while the lowest concentration were retrieved on the arable cropping system, both irrigated (ACI) and rainfed (ACR) (Figure 2). Labile $\mathrm{C}$ average concentration ranged between $0.5 \%$ and $2.2 \%$ of the total soil $\mathrm{C}$ (Figure 3). No-labile C (NLC), in the $0-5 \mathrm{~cm}$ layer, ranged between 9.8 and $26.0 \mathrm{~g} \mathrm{~kg}^{-1}$ with the higher values observed on NAT and olive sites (OM and $\mathrm{OF}$ ) compared to the other land uses, which showed 
values between the lowest limit and $15.3 \mathrm{~g} \mathrm{~kg}^{-1}$ (Figure 2). Stable organic $\mathrm{C}$ represented from $32 \%$ to $91 \%$ of the total soil C (Figure 3). Higher values were observed on all tree crop and natural soil covers compared to arable cropping systems and vineyard (Figure 3). In the deeper soil layer, $5-30 \mathrm{~cm}$, TIC concentration ranged from 1.2 to $17.2 \mathrm{~g} \mathrm{~kg}^{-1}$ and showed a similar trend to the $0-5 \mathrm{~cm}$ layer, with the highest concentration in arable cropping systems (ACI and ACR) and vineyard and the lowest under olive grove (OM and OF) (Figure 2). TIC, in the deeper soil layer, varied from $7 \%$ to $68 \%$ of the total soil $\mathrm{C}$ concentration (Figure 3). Soil POxC concentration ranged from 0.10 to $0.18 \mathrm{~g} \mathrm{~kg}^{-1}$ with the highest value observed on NAT, while the other land use had a similar concentration of about $0.14 \mathrm{~g} \mathrm{~kg}^{-1}$. Soil NLC concentration varied between 7.9 to $16.6 \mathrm{~g} \mathrm{~kg}^{-1}$ (Figure 2) being from $31 \%$ to $93 \%$ of the total soil C (Figure 3). Higher values in the $5-30 \mathrm{~cm}$ soil layer were observed on olive grove (OM and $\mathrm{OF}$ ) compared to the other land cover. Considering both labile and no-labile fractions, TOC ranged from 10.1 to $26.6 \mathrm{~g} \mathrm{~kg}^{-1}$ in the $0-5 \mathrm{~cm}$ soil layer and from 8.0 to $16.7 \mathrm{~g} \mathrm{~kg}^{-1}$ in the 5-30 cm soil layer (Figure 2). NAT and olive, both OM and OF, showed the highest values in the $0-5 \mathrm{~cm}$ soil layer $\left(25.7 \mathrm{~g} \mathrm{~kg}^{-1}\right.$, on average), while the other land cover showed values between 12.2 and $12.9 \mathrm{~g} \mathrm{~kg}^{-1}$, excluding ACI that showed a value equal to $10.1 \mathrm{~g} \mathrm{~kg}^{-1}$ (Figure 2). In the 5-30 $\mathrm{cm}$ soil layer, TOC showed a narrower range of variation than the $0-5 \mathrm{~cm}$ soil layer $(-32.6 \%)$, ranging between 8.0 and $16.7 \mathrm{~g} \mathrm{~kg}^{-1}$, with higher values on olive grove (both OM and OF) compared to the other land cover $\left(10.8 \mathrm{~g} \mathrm{~kg}^{-1}\right.$, on average). Different amplitude of TOC variation was observed between soil layers comparing land cover. NAT and olive grove difference mean value $\left(-16.4 \mathrm{~g} \mathrm{~kg}^{-1}\right.$ and $-10.2 \mathrm{~g} \mathrm{~kg}^{-1}$, respectively) were higher than other land covers $\left(-2.5 \mathrm{~g} \mathrm{~kg}^{-1}\right.$, on average) (Figure 2). Soil POxC, on average between land uses, represented about $2.0 \%$ of TOC in the upper soil layer $(0-5 \mathrm{~cm}$ soil layer) and $1.3 \%$ of TOC in the deeper soil layer $(5-30 \mathrm{~cm}$ soil layer).

Considering all land covers, the relationship between the two soil layer TOC concentrations was linear and positive in the range of $0-15 \mathrm{~g} \mathrm{~kg}^{-1}\left(\mathrm{Y}_{(\mathrm{TOC} 5-30 \mathrm{~cm})}=0.83 \mathrm{x}_{(\mathrm{TOC} 0-5 \mathrm{~cm})}-0.02\right)$. Above this range, the points distribution shows an upper limit, testifying that with an increase of TOC in the $0-5 \mathrm{~cm}$ layer, the TOC concentration in the $5-30 \mathrm{~cm}$ soil layer had a minimum effect $\left(\mathrm{Y}_{(\mathrm{TOC}} 5-30 \mathrm{~cm}\right)$ $\left.\left.=0.020 \mathrm{x}_{(\mathrm{TOC}} 0-5 \mathrm{~cm}\right)+12.8\right)$, highlighting the presence of a significant stratification of organic matter (Figure 4).

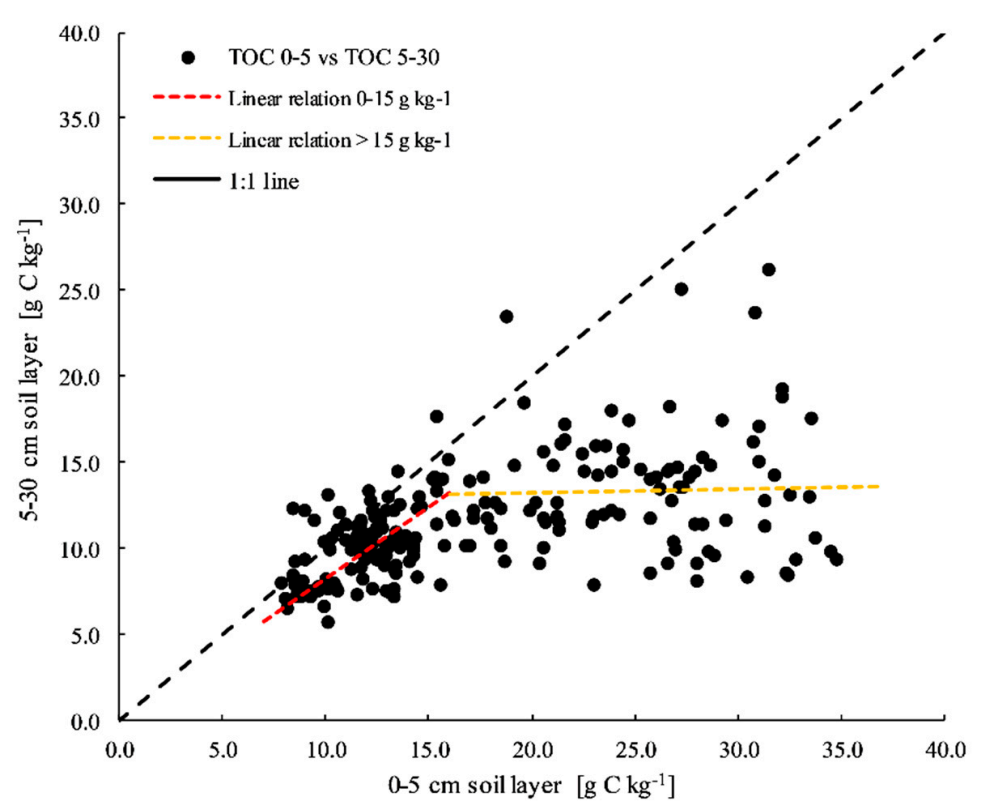

Figure 4. Relationships between soil TOC concentration at $0-5$ and $5-30 \mathrm{~cm}$ soil layers overall for all land uses studied $(n=420)$. Dotted lines represent linear regression within the interval $0-15 \mathrm{~g} \mathrm{~kg}^{-1}$ $\left(\mathrm{Y}_{(\text {TOC 5-30 cm })}=0.83 \mathrm{x}_{(\text {TOC } 0-5 \mathrm{~cm})}-0.02, \mathrm{R}^{2}=0.96, p<0.001\right)$ and $15-35 \mathrm{~g} \mathrm{~kg}^{-1}\left(\mathrm{Y}_{(\text {TOC } 5-30 \mathrm{~cm})}=\right.$ $\left.0.020 \mathrm{x}_{(\text {TOC } 0-5 \mathrm{~cm})}+12.8, \mathrm{R}^{2}=0.22, p>0.05\right)$. 
Soil organic $C$ stock in the $0-30 \mathrm{~cm}$ soil layer, on average among land covers, was of $42.9 \mathrm{Mg} \mathrm{C}$ $\mathrm{ha}^{-1}$, with a mean contribution of $10.3 \mathrm{MgC} \mathrm{ha}{ }^{-1}$ from the $0-5 \mathrm{~cm}$ soil layer and $32.6 \mathrm{MgC} \mathrm{ha}^{-1}$ from the $5-30 \mathrm{~cm}$ soil layer (Figure 5).

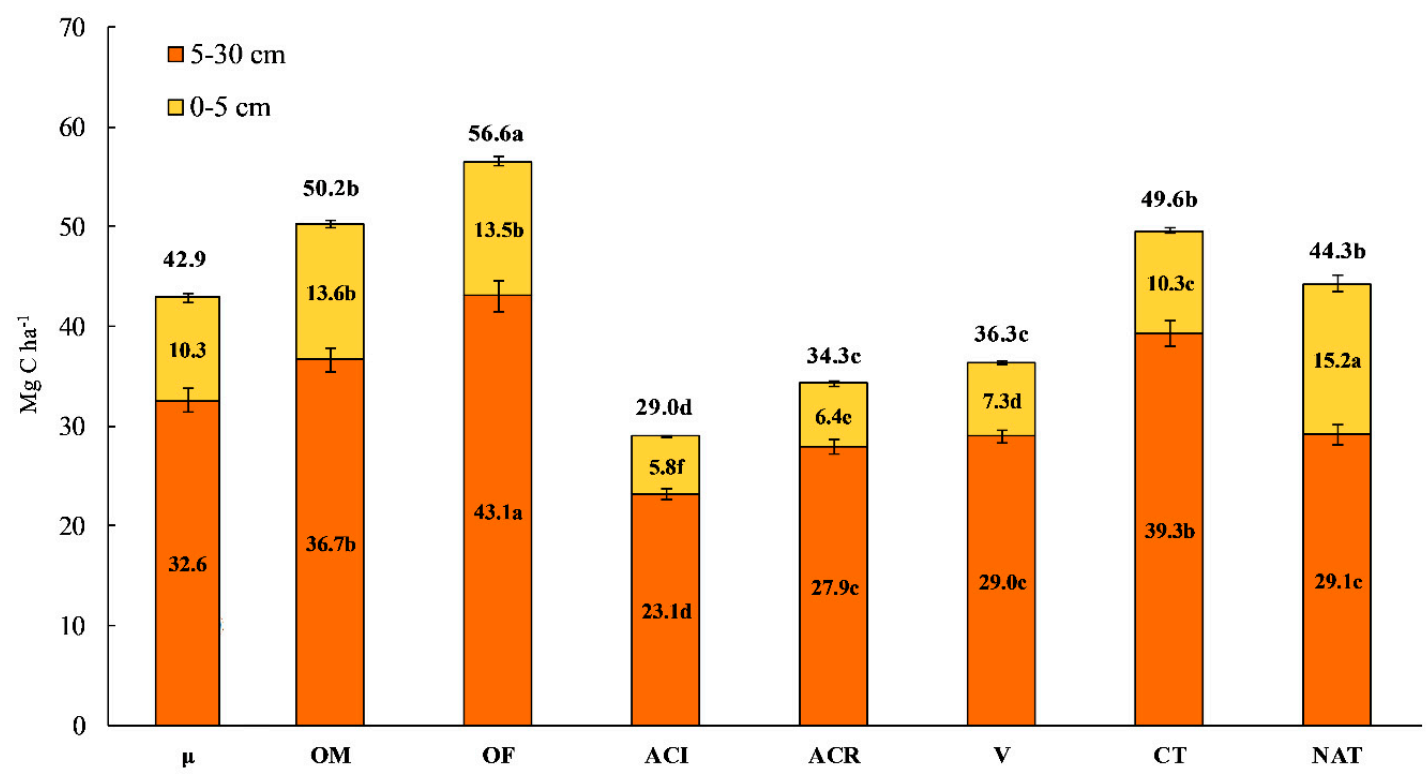

Figure 5. Soil organic $C$ stock in the $0-5 \mathrm{~cm}$ and $5-30 \mathrm{~cm}$ soil layer in the different land uses. $\mu$ : overall average values; OM: olive grove; OF: olive forest; ACI: arable crop irrigated; ACR: arable crop rainfed; V: vineyard; CT: citrus; NAT: Mediterranean scrub and garrigue. Reported values are means $(n=30)$ \pm SE (bars). Different letters indicate significant differences among agroecosystems (Duncan's test at $p<0.05)$.

Land uses showed organic $C$ stock values ranging from 29.0 to $56.6 \mathrm{Mg} \mathrm{C}^{-1}$ with values ranging from 5.8 to $15.2 \mathrm{MgC} \mathrm{ha}^{-1}$ in the $0-5 \mathrm{~cm}$ layer and from 23.1 to $43.1 \mathrm{Mg} \mathrm{C}^{-1}$ in the $5-30 \mathrm{~cm}$ layer (Figure 5). In the superficial soil layer $(0-5 \mathrm{~cm})$ the highest stock was retrieved in NAT soils, with intermediate levels in olive (OM and $\mathrm{OF})$ and $\mathrm{CT}\left(12.5 \mathrm{MgC} \mathrm{ha}^{-1}\right)$, and lower in the arable cropping system (ACI and $\mathrm{ACR})$ and $\mathrm{V}\left(6.5 \mathrm{Mg} \mathrm{C} \mathrm{ha}^{-1}\right.$, on average) (Figure 5). In the deeper soil layer $(5-30 \mathrm{~cm})$, the highest organic $\mathrm{C}$ stock was observed in OF $\left(43.1 \mathrm{Mg} \mathrm{C} \mathrm{ha}^{-1}\right)$ followed by CT $(39.3 \mathrm{Mg} \mathrm{C}$ $\mathrm{ha}^{-1}$ ) and $\mathrm{OM}\left(36.7 \mathrm{MgC} \mathrm{ha}{ }^{-1}\right)$, while concentrations between 27.9 and $29.1 \mathrm{MgCha}^{-1}$ were observed in ACR, V and NAT. The lowest level was observed in ACI (23.1 Mg C ha ${ }^{-1}$ ) (Figure 5). Between land cover overall values $(0-5 \mathrm{~cm}$ plus $5-30 \mathrm{~cm}$ ), OF showed the highest organic $\mathrm{C}$ stock with $56.6 \mathrm{Mg} \mathrm{C}$ $\mathrm{ha}^{-1}$ followed by OM with $50.2 \mathrm{Mg} \mathrm{C} \mathrm{ha}^{-1}$ and CT with $49.6 \mathrm{Mg} \mathrm{C} \mathrm{ha}^{-1}$. NAT showed a value of 44.3 $\mathrm{Mg} \mathrm{C} \mathrm{ha}^{-1}$, and lower and similar organic $\mathrm{C}$ stock were observed in $\mathrm{ACR}\left(34.3 \mathrm{MgC} \mathrm{ha}^{-1}\right)$ and V (36.3 $\left.\mathrm{Mg} \mathrm{C} \mathrm{ha}{ }^{-1}\right)$, while the lowest value was observed in $\mathrm{ACI}\left(29.0 \mathrm{MgC} \mathrm{ha}^{-1}\right)$ (Figure 5).

\subsection{Pearson's Correlations}

Pearson correlations showed that both TOC and POxC, at the topsoil layer $(0-5 \mathrm{~cm})$ were linearly and positively related with a large number of variables ( 23 and 22 out of 27 , respectively) comprising soil and WorldClim bioclimatic indexes (BIO01-BIO19; Ai). In the deepest sampling layer $(5-30 \mathrm{~cm})$ similar linear relationships only in TOC were observed and the linearity was less evident (11 out of 27) in POxC (Table 3). 
Table 3. Pearson's coefficients and $p$-value of the correlations between soil, bioclimatic variables, TOC and POxC in the $0-5 \mathrm{~cm}$ and $5-30 \mathrm{~cm}$ soil layers. Significant values are shown in bold.

\begin{tabular}{|c|c|c|c|c|c|c|c|c|}
\hline & \multicolumn{4}{|c|}{ TOC } & \multicolumn{4}{|c|}{ POxC } \\
\hline & \multicolumn{2}{|c|}{$0-5 \mathrm{~cm}$} & \multicolumn{2}{|c|}{$5-30 \mathrm{~cm}$} & \multicolumn{2}{|c|}{$0-5 \mathrm{~cm}$} & \multicolumn{2}{|c|}{$5-30 \mathrm{~cm}$} \\
\hline & $\mathbf{r}$ & $p$-Value & $\mathbf{r}$ & $p$-Value & $\mathbf{r}$ & $p$-Value & $\mathbf{r}$ & $p$-Value \\
\hline TIC & -0.46 & $<0.0001$ & -0.33 & $<0.0001$ & -0.42 & $<0.0001$ & -0.09 & 0.205 \\
\hline $\mathrm{pH}$ & -0.70 & $<0.0001$ & -0.48 & $<0.0001$ & -0.57 & $<0.0001$ & -0.09 & 0.196 \\
\hline $\mathrm{EC}$ & -0.01 & 0.870 & -0.27 & $<0.0001$ & 0.09 & 0.200 & 0.12 & 0.083 \\
\hline BD & -0.22 & 0.002 & -0.26 & $<0.0001$ & -0.16 & 0.021 & -0.21 & 0.003 \\
\hline Sand & -0.48 & $<0.0001$ & -0.23 & 0.001 & -0.45 & $<0.0001$ & -0.15 & 0.029 \\
\hline Silt & 0.50 & $<0.0001$ & 0.29 & $<0.0001$ & 0.41 & $<0.0001$ & 0.14 & 0.048 \\
\hline Clay & 0.26 & $<0.0001$ & 0.22 & 0.002 & 0.40 & $<0.0001$ & 0.13 & 0.046 \\
\hline BIO01 & -0.12 & 0.094 & -0.01 & 0.901 & -0.02 & 0.804 & 0.01 & 0.914 \\
\hline $\mathrm{BIO} 2$ & -0.22 & 0.001 & -0.07 & 0.339 & -0.32 & $<0.0001$ & 0.25 & $<0.0001$ \\
\hline BIO03 & 0.13 & 0.053 & 0.21 & 0.751 & 0.06 & 0.357 & 0.15 & 0.026 \\
\hline BIO04 & -0.53 & $<0.0001$ & -0.40 & $<0.0001$ & -0.53 & $<0.0001$ & 0.13 & 0.067 \\
\hline BIO05 & -0.40 & $<0.0001$ & -0.19 & 0.007 & -0.39 & $<0.0001$ & 0.13 & 0.059 \\
\hline BIO06 & 0.13 & 0.057 & -0.17 & 0.015 & 0.27 & $<0.0001$ & -0.18 & 0.007 \\
\hline BIO07 & -0.43 & $<0.0001$ & -0.25 & 0.001 & -0.49 & $<0.0001$ & 0.21 & 0.002 \\
\hline BIO08 & -0.68 & $<0.0001$ & -0.52 & $<0.0001$ & -0.64 & $<0.0001$ & -0.05 & 0.484 \\
\hline BIO09 & -0.42 & $<0.0001$ & -0.24 & 0.001 & -0.35 & $<0.0001$ & 0.06 & 0.378 \\
\hline BIO10 & -0.34 & $<0.0001$ & -0.19 & 0.007 & -0.26 & $<0.0001$ & 0.06 & 0.427 \\
\hline BIO11 & 0.11 & 0.120 & 0.17 & 0.011 & 0.19 & 0.005 & -0.06 & 0.395 \\
\hline BIO12 & 0.51 & $<0.0001$ & 0.40 & $<0.0001$ & 0.48 & $<0.0001$ & -0.10 & 0.143 \\
\hline BIO13 & 0.44 & $<0.0001$ & 0.51 & $<0.0001$ & 0.35 & $<0.0001$ & -0.06 & 0.409 \\
\hline BIO14 & 0.57 & $<0.0001$ & 0.48 & $<0.0001$ & 0.54 & $<0.0001$ & -0.09 & 0.186 \\
\hline BIO15 & -0.16 & 0.024 & 0.09 & 0.173 & -0.28 & $<0.0001$ & 0.22 & 0.001 \\
\hline BIO16 & 0.44 & $<0.0001$ & 0.47 & $<0.0001$ & 0.36 & $<0.0001$ & -0.06 & 0.386 \\
\hline BIO17 & 0.32 & $<0.0001$ & 0.14 & 0.047 & 0.37 & $<0.0001$ & -0.20 & 0.003 \\
\hline BIO18 & 0.46 & $<0.0001$ & 0.25 & 0.001 & 0.49 & $<0.0001$ & -0.14 & 0.041 \\
\hline BIO19 & 0.40 & $<0.0001$ & 0.27 & $<0.0001$ & 0.32 & $<0.0001$ & -0.06 & 0.389 \\
\hline $\mathrm{Ai}$ & 0.46 & $<0.0001$ & 0.33 & $<0.0001$ & 0.44 & $<0.0001$ & -0.15 & 0.301 \\
\hline
\end{tabular}

In particular, at the $0-5 \mathrm{~cm}$ soil layer, soil properties, excluding EC, had a significant negative effect $(p<0.001)$ on TOC accumulation, particularly $\mathrm{pH}(\mathrm{r}=-0.70)$. TOC concentration also linearly decreased with increasing of sand $(\mathrm{r}=-0.48 ; p>0.001)$ but increased as clay and silt increased $(\mathrm{r}=0.50$ and $\mathrm{r}=0.26$, respectively; $p<0.0001$ ), The temperature-related indexes (BIO01-BIO10), excluding the not significant BIO01, BIO03 and BIO06, showed negative linear relations with TOC at the topsoil layer; linearity was stronger versus BIO04 and BIO08 ( $r>0.50 ; p<0.001)$. In the same soil layer, TOC resulted positively and significantly related with precipitation-related indexes, from BIO12 to BIO19, resulting $r>0.40$ in 7 indexes out of 9, as well as in $\mathrm{Ai}(\mathrm{r}=0.46)$ (Table 3). As observed in the top layer, in the $5-30 \mathrm{~cm}$ soil layer correlations between TOC and soil variables were negative and significant with TIC $(\mathrm{r}=-0.33), \mathrm{pH}(\mathrm{r}=-0.48), \mathrm{EC}(\mathrm{r}=-0.27)$ and $\mathrm{BD}(\mathrm{r}=-0.26)$. Moreover, correlation of TOC with the textural fractions were even more significant $(p<0.0001)$ : negative for sand $(r=-0.23)$ and positive for silt and clay $(r=0.29$ and $r=0.22$, respectively). The higher significances $(p<0.001)$ among the many negative correlations between TOC accumulation in the 5-30 cm layer and temperature-related indexes were founded in BIO04 and BIO08 $(\mathrm{r}=-0.40$ and $\mathrm{r}=-0.52$, respectively). Among the pluviometric indexes many more variables highly significant related to POxC $(p<0.0001)$ were highlighted and, in particular, BIO13, BIO14 and BIO16 showed the highest correlation coefficients $(r>0.45)$. Similarly, to what found for TOC, in the $0-5 \mathrm{~cm}$ soil layer POxC was significantly $(p<0.001)$ related with soil variables TIC, $\mathrm{pH}$ and even with textural fractions resulting in $r>0.40$ (Table 3). Furthermore, highly significant linear relationships between POxC and temperature-related indexes were also observed $(p<0.001)$ as in the case of BIO04, BIO07 and BIO08 
$(\mathrm{r}=0.53 ; \mathrm{r}=0.49$ and $\mathrm{r}=0.64$, respectively). Additionally, for the rainfall indexes, Pearson correlations analysis showed a high significant correspondence with the POxC in the topsoil layer. In particular, a relationship with stronger linearity were observed between POxC and BIO14, BIO18 and BIO12 $(\mathrm{r}=0.54 ; \mathrm{r}=0.49 ; \mathrm{r}=0.48$, respectively) as well as with $\mathrm{Ai}(\mathrm{r}=0.44)$. With regard to the $5-30 \mathrm{~cm}$ soil layer, it was more difficult to find a linear correlation between variables and soil POxC concentration. A significant relation $(p<0.05)$ of soil particle distribution on the three principal dimensional classes appeared, while the effect of temperature and precipitation was less clear (Table 3).

\subsection{Multiple Linear Regressions}

MLR models calculated by the stepwise regression analysis are presented in Table 4 .

Table 4. Multiple linear regression for the estimation of soil TOC and POxC concentration in the $0-5 \mathrm{~cm}$ and $5-30 \mathrm{~cm}$ soil layers $(n=210)$.

\begin{tabular}{|c|c|c|c|c|c|}
\hline \multicolumn{3}{|c|}{ TOC (g kg-1) } & \multicolumn{3}{|c|}{ POxC (g kg-1) } \\
\hline$y$ & $x$ & $m$ & $y$ & $x$ & $m$ \\
\hline \multirow[t]{8}{*}{$0-5 \mathrm{~cm}$} & $\mathrm{BD}\left(\mathrm{g} \mathrm{cm}^{-3}\right)$ & -31.03 & $0-5 \mathrm{~cm}$ & pH (-) & -0.030 \\
\hline & Clay (\%) & 2.46 & & $\mathrm{BD}\left(\mathrm{g} \mathrm{cm}^{-3}\right)$ & 0.304 \\
\hline & BIO03 & -2.37 & & PSD (0.03 mm) (\%) & 0.011 \\
\hline & BIO04 & -0.02 & & BIO01 & 0.031 \\
\hline & BIO08 & -0.48 & & $\mathrm{BIO} 13$ & 0.002 \\
\hline & BIO17 & -0.57 & & BIO14 & 0.073 \\
\hline & BIO19 & -0.03 & & BIO17 & -0.008 \\
\hline & Constant & 340.72 & & Constant & -2.737 \\
\hline $\mathrm{R}^{2}=0.86$ & $\mathrm{~F}=100.0$ & $p<0.0001$ & $\mathrm{R}^{2}=0.86$ & $\mathrm{~F}=107.1$ & $p<0.0001$ \\
\hline \multirow[t]{8}{*}{$5-30 \mathrm{~cm}$} & pH (-) & 0.61 & $5-30 \mathrm{~cm}$ & TIC $\left(\mathrm{mg} \mathrm{kg}^{-1}\right)$ & -0.091 \\
\hline & $\mathrm{BD}\left(\mathrm{g} \mathrm{cm}^{-3}\right)$ & -15.51 & & Silt $(\%)$ & 0.002 \\
\hline & PSD $(1.4 \mu \mathrm{m})(\%)$ & 4.60 & & Clay (\%) & 0.009 \\
\hline & BIO08 & -0.14 & & BIO07 & 0.010 \\
\hline & BIO14 & -1.38 & & BIO09 & -0.025 \\
\hline & BIO18 & -0.30 & & BIO10 & 0.023 \\
\hline & BIO19 & -0.02 & & BIO14 & 0.032 \\
\hline & Constant & 37.58 & & Constant & -2.25 \\
\hline $\mathrm{R}^{2}=0.76$ & $F=59.66$ & $p<0.0001$ & $\mathrm{R}^{2}=0.70$ & $F=50.6$ & $p<0.0001$ \\
\hline
\end{tabular}

Stepwise linear regressions revealed the different impact of soil and bioclimatic variables on TOC and POxC stocks with high precision. In all analyses, the coefficient of determination $\left(R^{2}\right)$ was never less than 0.70. MLR models allowed us to select the most relevant variables related to TOC and POxC in the two soil layers investigated. With regard to the TOC, in both soil layers, clay content, and more precisely the concentration of the finest soil particles, together with BD were the most relevant soil properties, while the indexes of thermal excursion (BIO03, BIO04), temperature on rainy period (BIO08) and the rainfall in extreme periods, hot and cold (BIO18, BIO19), were the significant bioclimatic data (Table 4). In the deeper soil layer, the incidence of temperature-related indexes was lower than in the upper one. Relatively to the soil properties, TOC accumulation was negatively correlated to soil $\mathrm{BD}$ and positively with the soil's finest particle content. Among bioclimatic data, TOC showed a negative correlation with all indexes, especially with those that take into account temperature and precipitation in the extreme period (BIO08, BIO17, BIO14, BIO18) (Table 4). Soil POxC was positively related to $\mathrm{BD}$ and fine soil particles (silt and clay) and negatively with TIC and $\mathrm{pH}$. Among bioclimatic data, significant and positive relationships were observed with the precipitation in the driest month (BIO14). Furthermore, in the deeper soil layer, annual air temperature range (BIO07) showed a positive correlation, while air temperature during the wettest and driest quarter (BIO09 and BIO10) showed an opposite trend between them (Table 4). 


\subsection{Principal Component Analysis}

Principal component analysis was performed in order to describe the overall pattern of sensitivity of all measured soil variables, together with bioclimatic data, to the soil TOC and POxC in the different ecosystems. PCA for TOC and POxC clearly discriminated the seven sampling areas (Figure 6).

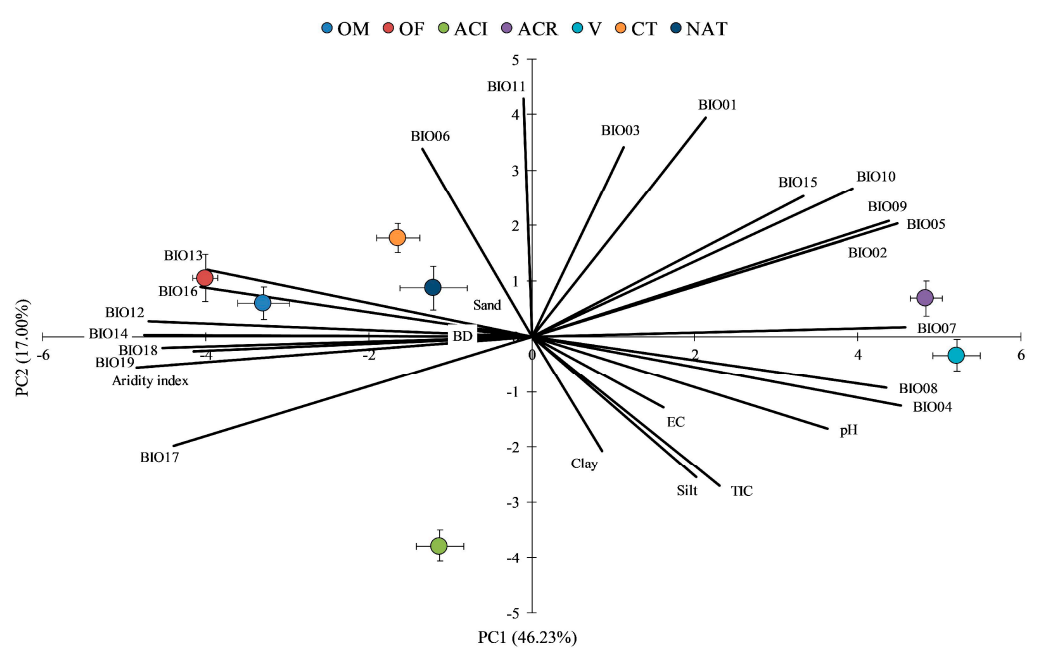

(a)

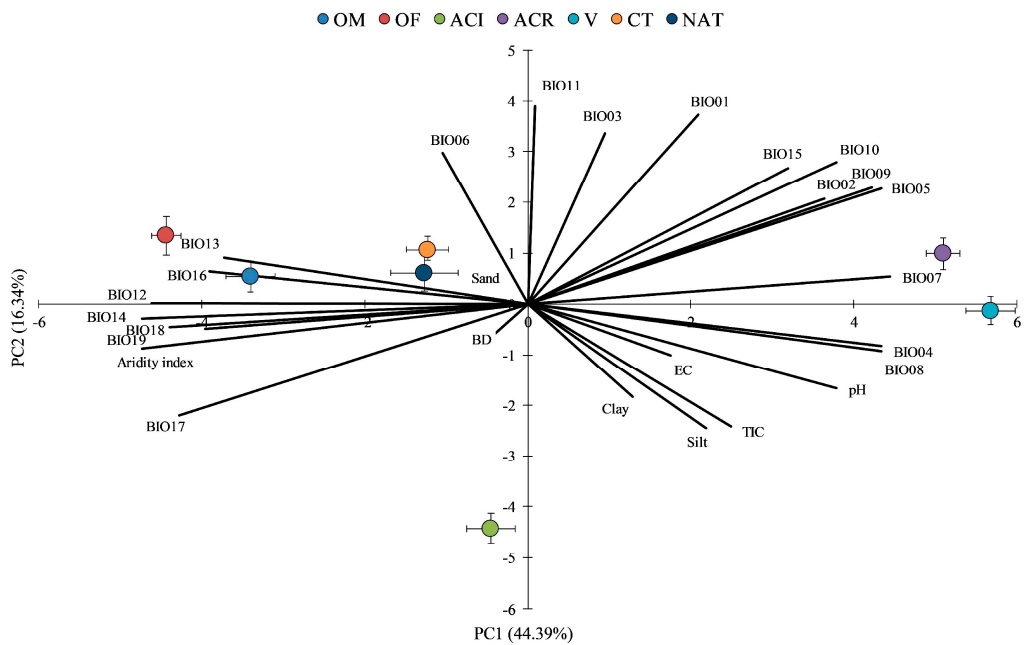

(b)

Figure 6. Principal component analysis biplot of the seven sampled agroecosystems for soil TOC (a) and POxC (b) concentration. PC1: first component variable; PC2: second component variable. The direction and length of each line indicate the degree of association between each soil properties and bioclimatic variables with TOC and POxC values in the sampled agroecosystem. OM: olive grove; OF: olive forest; ACI: arable crop irrigated; ACR: arable crop rainfed; V: vineyard; CT: citrus; NAT: Mediterranean scrub and garrigue. Comparisons of Mahalanobis squared distances showed highly significant differences $(p<0.01)$ in the soil, climatic and bioclimatic variables among agroecosystems.

With regard to TOC, the first two principal components accounted for about $63 \%$ of the total variance. PC1, contributed for $46.23 \%$ of the total variance and, among soil properties, was positively correlated with clay, silt, TIC, EC and $\mathrm{pH}$ and negatively with BD and sand. Between the bioclimatic indexes, PC1 allowed us to discriminate the effect of temperature-related indexes compared to those related to precipitation on the study sites. PC2 explained $17.00 \%$ of variance; the soil properties with the higher influence were sand (positive), clay and silt (negative) (Figure 6). Among bioclimatic data, PC2 slightly separated the precipitation indexes from the dry and warm season from those of the wet and cold period, and temperature seasonality (BIO04) from rainfall seasonality (BIO15). PC1 separated 
$\mathrm{V}$ and ACR from OM-OF, CT-NAT and ACI, while PC2 distinguished among ACI and $\mathrm{V}$ and all other land covers (Figure 6). With regard to soil POxC stock, the first two components explained about $61 \%$ of the total variance; PC1 contributed $44.39 \%$, and PC2 contributed $16.34 \%$. Discrimination between land cover, correlations between principal components and studied pedoclimatic variables were similar to those observed for TOC.

\subsection{Variance Partitioning}

Variance partitioning analysis showed that for TOC, on average between both soil layers investigated, about $80 \%$ of variation was explained by the factors considered (Figure 7).

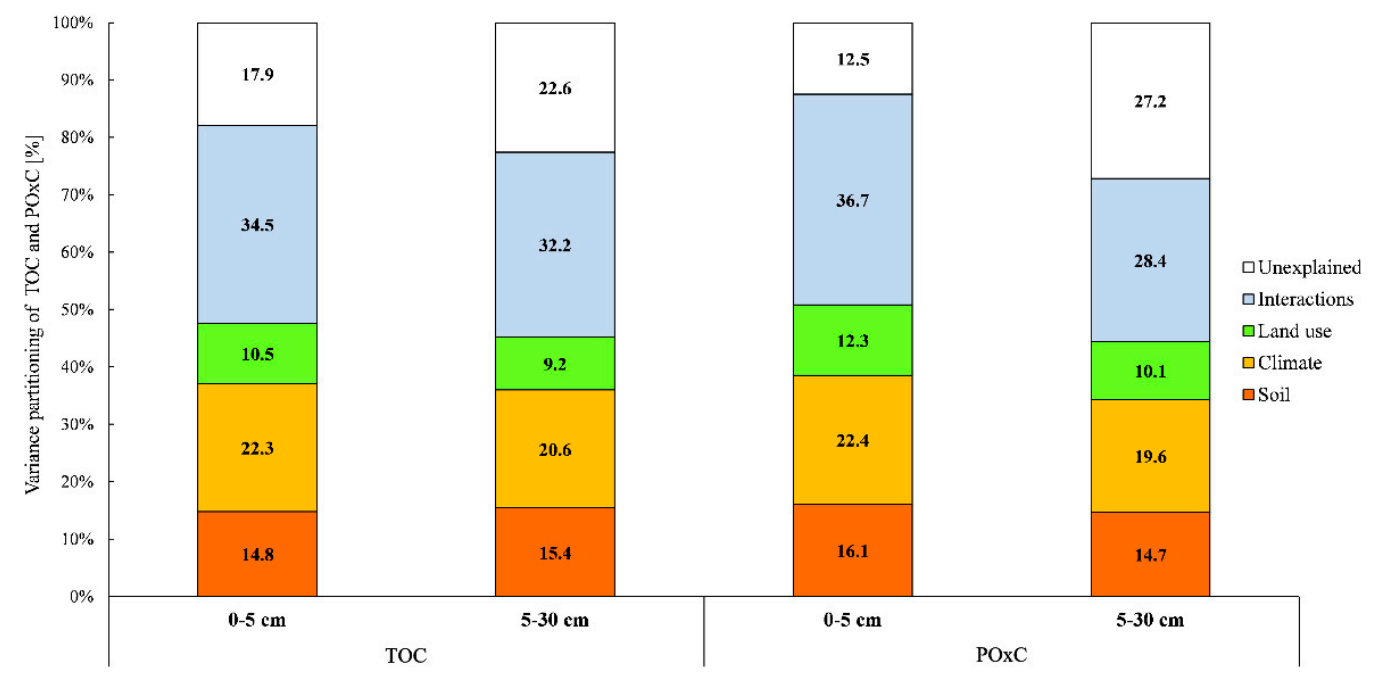

Figure 7. Contribution of land use, bioclimatic variables and soil parameters to the proportion of explained variation (\%) of TOC and POxC in $0-5$ and 5-30 cm soil layers in the seven agroecosystems studied, determined from the variance partitioning. The number in each bar represents the explained variation by the corresponding factor. The interaction effect represents the proportion of variation shared between all factor, while the unexplained portion is the variation that is not possible to attribute to any considered factors (land use, climate, soil).

In particular, soil properties accounted for $15.1 \%$ of variation while a higher contribution was observed from climate, about $21.5 \%$. Land use represented itself $9.8 \%$ of variance. With regard to the POxC, a similar incidence of each factor compared to what has been observed for TOC was observed. For both soil $\mathrm{C}$ pools studied, interactions between factors represented the highest proportion of explained variance, accounting for 33.4\% in TOC and 32.6\% in POxC. Among the soil layers investigated, both for TOC and POxC, a higher unexplained variation was observed in the deeper soil layer $(5-30 \mathrm{~cm})$ than in the superficial ones $(0-5 \mathrm{~cm})(24.9 \%$ vs. $15.2 \%$, on average) (Figure 7$)$.

\section{Discussion}

\subsection{Soil TOC, C Stock and POxC Concentration}

Measured TOC and C stock levels showed similar values compared to other studies performed in Mediterranean areas [4,10,37-42]. The average TOC content in the soils of the sampled areas was $42.9 \mathrm{Mg} \mathrm{C} \mathrm{ha}{ }^{-1}$ and fell within the range of values reported for other European countries. In general, our results agree with Farina et al. [40], who found in a Southern Italy survey TOC values in rangelands higher than in croplands. This evidence partially follows the different net primary production, which is generally higher in natural ecosystems than in croplands and in trees than in annual crops [43]. With regard to the specific land uses in the present study, some differences were observed compared to other studies. In particular, the olive grove, both modern and forest, showed the largest soil $\mathrm{C}$ 
stock compared with other cropland according to Chiti et al. [37], who observed $51.5 \mathrm{Mg} \mathrm{C} \mathrm{ha}^{-1}$ in the 0-30 cm soil layer, and to Novara et al. [44] who reported $53 \mathrm{Mg} \mathrm{Cha}^{-1}$ in the $0-40 \mathrm{~cm}$ soil layer. On the other hand, our results disagree with those obtained by Muñoz-Rojas et al. [10] in Southern Spain (16.4 Mg C ha ${ }^{-1}$ in the $0-25 \mathrm{~cm}$ soil layer) and by Muñoz-Rojas et al. [45] in Northern Egypt (14.5 Mg C $\mathrm{ha}^{-1}$ in the $0-25 \mathrm{~cm}$ soil layer). Moreover, the value of $36.3 \mathrm{MgC} \mathrm{ha}^{-1}$ obtained in the vineyard study site was similar to that observed in France by Martin et al. [46] and Meersmans et al. [47] (39.4 and $32.7 \mathrm{Mg} \mathrm{C} \mathrm{ha}{ }^{-1}$, respectively) and in Spain by Rodríguez-Murillo [48] (42.5 $\left.\mathrm{Mg} \mathrm{C} \mathrm{ha}^{-1}\right)$. Our results from arable cropping systems in the $0-30 \mathrm{~cm}$ soil layer were 29.0 and $34.3 \mathrm{Mg} \mathrm{C}^{-1}$, respectively, from irrigated and rainfed, in agreement with data from the $0-25 \mathrm{~cm}$ soil layer $\left(31.7 \mathrm{MgC} \mathrm{ha}^{-1}\right)$ obtained by Muñoz-Rojas et al. [45]. Soil C stock found in our arable cropping system under rainfed conditions was higher than in irrigated systems as also observed by Mudge et al. [49]. Citrus cultivation provided values (46.9 Mg C ha-1) similar to those by Chiti et al. [37] (44.1 $\mathrm{Mg} \mathrm{C} \mathrm{ha}^{-1}$ ), while Mediterranean natural land cover, consisting of scrub and garrigue, showed an intermediate $\mathrm{C}$ stock compared to arable and woody crops (44.3 $\mathrm{Mg} \mathrm{C} \mathrm{ha}^{-1}$ ) with lower values than Novara et al. [44] (112 $\left.\mathrm{Mg} \mathrm{ha}^{-1}\right)$, but similar to Alberti et al. [50] (47.6 $\left.\mathrm{Mg} \mathrm{ha}^{-1}\right)$ and Francaviglia et al. [42] (40.6 $\mathrm{Mg} \mathrm{ha}^{-1}$ in the $0-25 \mathrm{~cm}$ soil layer) falling within the range reported by Muñoz-Rojas et al. [10] for this land use. As observed by Li et al. [51], natural land cover showed higher TOC concentration than cropland. The higher TOC in natural areas can be associated with the larger annual addition of leaf litter combined with the absence of any soil disturbance such as tillage [52,53]. With regard to tillage, an inverse correlation among soil perturbation intensity of agroecosystems and TOC pool was retrieved, so as to highlight differences between conventionally tilled and no-till systems (CT, V, ACI, ACR vs OF, OM). These results corroborate the role of tillage on the destruction of soil structure and physical changes, which stimulate microbial activity and expose a larger organic fraction to mineralization [54,55].

Since TIC stock can play an important role in C cycling and climate change [56], estimates of inorganic $C$ stocks is of considerable importance [57]. Indeed, in three different areas (i.e., vineyard and both arable crops) soil inorganic $C$ represented more than half of the total $C$ content, reaching in some cases two thirds of the total soil $\mathrm{C}$ stock. Nevertheless, arid and semi-arid climatic conditions could greatly contribute, as soil-forming factors, to the formation of carbonate, as also argued by Tan et al. [58]. Further, together with the geological, pedogenetic and climatic processes, a negative relationship between TOC and TIC could be established as a result of carbonate dissolution during TOC decomposition [17].

Labile soil C stock, like POxC, comprises several easily decomposable substrates (i.e., polysaccharides, a fraction of microbial biomass) and was proposed as a reliable soil variable to predict soil nutrient availability and long-term soil $C$ dynamics [26,59]. With regard to the upper soil layer $(0-5 \mathrm{~cm})$, Mediterranean scrubs, tree crops and vineyard showed higher concentrations than arable crops areas. This is consistent with previous studies that reported POxC levels in uncultivated and forest soils higher than in cultivated soils [60]. This suggests that different quantities and qualities of biomass input, as well as its degradation process, can have a significant effect on soil POxC levels. In particular, among the studied ecosystems, tree crops with deeper roots and larger above-ground C-inputs, such as leaf litter, can greatly contribute to soil C accumulation [53], whereas in croplands, residue removal and intensive tillage practices stimulate soil $\mathrm{C}$ mineralization and promote rapid labile $\mathrm{C}$ oxidation [61]. Moreover, the highest supply of organic matter in the surface layer was coupled with a more active $\mathrm{C}$ mineralization processes, which contributed to the release of $C$ labile, as argued by Hiederer [62]. In the deeper soil layer, on the contrary, differences among systems were reduced as a probable result of superficial litter effect disappearance. On average, soil POxC accounted for $2.0 \%$ and $1.3 \%$ of TOC in the $0-5$ and $5-30 \mathrm{~cm}$ soil layers, respectively, falling into the range of $1 \%-5 \%$ presented by several authors [26]. Finally, a good correlation between soil POxC and NLC globally for both soil layers was found $\left(R^{2}=0.62\right)$, confirming the good aptitude of this parameter to predict the TOC stabilization process in the soil according with Hurisso et al. [59]. As revealed also from POxC data, Calabrian agroecosystems showed different patterns of TOC stratification along the soil profile. Although TOC 
concentration was always higher in the topsoil $(0-5 \mathrm{~cm})$ than in subsoil, the reduction in concentration between the two layers was a function of land use. As referred for POxC, TOC stratification can be ascribed to several factors, namely residue deposition on topsoil, soil disturbance and crop management, especially tillage [63]. This evidence was observed also by several authors [44,64,65]. In particular, as shown in Figure 5, a linear relationship between top and subsoil $C$ concentration was attained for the range $0-15 \mathrm{~g} \mathrm{~kg}^{-1}$. This occurred in four out of seven land uses (namely CT, V, ACI, ACR). These four land uses are characterized by a higher soil disturbance compared to olive grove and undisturbed scrubs areas. Indeed, citrus and vineyard, as well as arable crop, are subjected to regular and repeated soil tillage during cropping season, while olive trees in Calabria are generally managed by no till use. This confirms that tillage can be the main factor responsible for TOC gradients along the profile in agricultural soils $[66,67]$ and could contribute to subsoil $C$ storage $[42,65]$, especially under Mediterranean climatic conditions where water transport is limited. Among agroecosystems, the amount of $C$ stock per $\mathrm{cm}$ of depth, calculated as the ratio between the $C$ stock divided by soil layer depth, showed higher concentration in topsoil than in subsoil, confirming that in addition to a faster mineralization, in deeper layers a more efficient immobilization process also occurs $[41,62,66,68]$.

\subsection{Main Factors Affecting C Accumulation}

A wide range of local site variables can be related to TOC distribution on agroecosystems linked to soil properties or climate that determine the processes of organic matter from its formation, to transformation, until the stabilization into the soil [65]. Among soil properties, as observed by Pearson correlation coefficients and the MLR approach, a great contribution to soil organic matter derived from silt and clay particles that showed a significant influence on both total and labile forms. Primarily, fine soil particles had a positive effect on soil water holding capacity and thus on plant biomass production [69]. After that, as argued by Kiem et al. [70], TOC dynamics are slowed down by silt and clay due to physical mechanisms of protection against oxygen diffusion and the attack of soil microorganisms, absorbing organic matter on soil structure and stabilizing it [9]. This double action mechanism has been supported by different $C$ surveys around the world $[5,68,71]$. Another soil property that can play an important and significant role on $\mathrm{C}$ dynamics is $\mathrm{pH}$; varying from each sampling areas and affecting soil reduction and oxidation processes into the soil can determine the fate of $C$ substrate addressing to accumulation or mineralization [72] and vice versa. Indeed, in our soil survey, $\mathrm{C}$ accumulation in acid and sub-acid soil (OM, OF, CT, NAT) was higher than under neutral $\mathrm{pH}(\mathrm{ACI}, \mathrm{ACR}, \mathrm{V})$, thus confirming the negative correlation between soil $\mathrm{pH}$ and TOC content, as also observed by other authors [73], who related higher $\mathrm{pH}$ values to higher microbial mineralization activity. Soil $\mathrm{pH}$, furthermore, is an important factor revealing TIC distribution across land uses and soil acidification processes [5]. Together with the $\mathrm{pH}, \mathrm{EC}$ can play an important role in TOC distribution, addressing organic matter decomposition affecting soil functioning such as microbial activity and hydrology [74]. As a result of soil texture and management practices, bulk density represents an important physical variable affecting soil $\mathrm{C}$ sequestration as it controls macro and microporosity distribution and hence the microbial access to soil water and air volumes. Shifts to this ratio can have a significant effect on soil $\mathrm{C}$ decomposition and immobilization processes, establishing a negative correlation between BD and TOC [75]. Climate variables give a great contribution in explaining TOC distribution across land use at the regional scale [76]. Del Grosso et al. [77] observed that temperature and precipitation parameters can explain more than $50 \%$ of TOC regional variability. As revealed from our analysis, in the complex interaction between climate and soil C, a clear and contrasting trend between temperature and precipitation was observed. The role of temperature on TOC depends on its influence on the soil microbial community and organic matter decomposition. Indeed, low temperature inhibits microbial activity and can lead to reduced $C$ mineralization, increasing $\mathrm{C}$ stock $[78,79]$. This effect was confirmed in our study by the negative Pearson correlations found between TOC and the temperature-related indices used. However, although some authors reported that an increase of temperature can result in higher plant growth and productivity associated with 
a higher litter deposition, we hypothesize that in the study areas the temperature did not represent a limiting factor for plant production. The precipitation effect can be directly associated with an increase of net primary production of agroecosystems, thus increasing organic matter deposition in soil [71]. According to Deng et al. [76], in our study a positive correlation among TOC and annual precipitation was retrieved. However, a similar correlation has not been observed by other authors in Italy [38,50], which is probably due to the low annual rainfall that never exceeds $1000 \mathrm{~mm}$ in our sampling areas. Indeed, in arid and sub-arid agroecosystems, precipitation can stimulate plant production more than the microbial decomposition processes [64]. That was also confirmed by the positive correlation between Ai and measured TOC, as also observed by Delgado-Baquerizo et al. [80] and Rial et al. [81]. Therefore, our study agrees with Conforti et al. [71], who highlighted cool and wet climatic conditions as more favorable to $C$ accumulation in Calabrian soils. Effects from climate variables were also confirmed by the relations between TOC and some bioclimatic parameters, as highlighted by Pearson coefficients and MLR analysis. An in-depth analysis of MLR highlighted an interacting effect between temperature and rainfall, related to the rainfall in dry and warm period represented by BIO14, BIO17 and BIO18 indexes, showing a negative relation with TOC concentration. This evidence points out what was said above, indicating also how the association between higher temperature and rainfall, and therefore high soil water contents, can stimulate soil microbial activity and hence organic matter depletion. Besides, based on the rainfall seasonality and distribution [82], these indicators can also lead to suppose a great effect of short rain events during late summer and autumn that can cause rapid variation of soil water content and related soil respiration flushes [83]. The climate effect was higher in the upper soil layer than in the deeper one, as also reported by Wagai et al. [84] and Willaarts et al. [39]. Soil physico-chemical variables as well as climatic factors showed a different impact on the soil organic pool of specific land uses. The principal component analysis allowed us to strongly discriminate the studied agroecosystems by climate characteristics indicating in climate the major factor explaining TOC distribution [39]. Indeed, OF, OM, CT, NAT and ACI were clearly separated from $\mathrm{V}$ and ACR by bioclimatic indexes, pointing out also a separation between temperature and rainfall indices. This evidence can result from the different distribution of land uses within the Calabrian region with OF, OM, CT, NAT distributed along the Tyrrhenian coast, whereas $\mathrm{V}$ and $\mathrm{ACR}$ are sites along the Ionian coast, confirming the trend observed by Versace et al. [85] and Capra et al. [86] among these areas, with higher rainfall along Tyrrhenian than Ionian coast and an opposite trend with regard to temperature regime, with consequences on TOC stock. Moreover, this discrimination can also be imputable to the finer soil texture observed in ACR and V, represented by long PC2, although to a lesser extent than climate parameters. The minor differences observed between olive tree areas (both OM and OF), NAT and ACI can be related to differences on climate of these agricultural districts and their soil textures. Among arable cropping systems (ACI and ACR), PCA evidenced a high discrimination between them. Indeed, these areas showed great differences in climate and their management. A significant differentiation was caused by the BIO17 index, representing the precipitation in the summer, indicating higher seasonal aridity in ACR than in ACI. Moreover, these differences can be exacerbated by irrigation in ACI. Needless to say, irrigation can play an important role in promoting TOC decomposition.

\subsection{Contribution of Each Group of Edaphic Factor to C Soil Stocks}

The variation partitioning analysis demonstrated that large parts (amounts) of TOC and POxC, in both layers investigated, could be explained by the combined effects of soil properties and climate variables. The relative contribution of soil properties and climate to TOC and POxC was also mediated by land use. Among the edaphic factors, climatic parameters help to explain the higher proportions of variations, although better in the surface than in the deeper soil layer. The greater weight of climate than other factors in determining C stock in the soils was also recognized by some authors [64], whereas others pointed out the reduction of the climate effect from surface to deep soil layers [39]. Not in accordance with our findings, other authors [4] reported in a Mediterranean environment 
a higher contribution of soil variables than climate; however, this discrepancy could be related to the higher investigated surface and soil heterogeneity found among sampling areas. Land use and management had a secondary role explaining, on average, about $10.5 \%$ of SOC and POxC variation, showing similar values observed by Rabbi et al. [87]. Beside the aforementioned factors, however, the interaction between them could explain about a third of all variance. This evidence confirms how TOC accumulation and organic matter decomposition are the result of several different complex interactions, leading us to suppose that relatively small changes, especially with regard to climate parameters, can have a considerable effect on soil TOC and POxC deriving from a direct and indirect effect. The unexplained variance, larger in deeper than in surface soil layers, can indicate the influence of several factors not considered in the present work (such as soil discontinuity, micro-topography, exposure, local drainage, specific management) that can drive TOC variation at the agroecosystem scale $[39,53]$.

\section{Conclusions}

Soil TIC, TOC and POxC distribution on most common land use across the Calabrian region, as well as the relationship with soil properties and climate variables, were studied. In particular, with regard to the first objective, our results highlighted that the agroecosystem where the most common tree crops of the region (olive and citrus) are grown can reach higher organic $C$ stocks in the soils, combining their economical gaining with high landscape and environmental values. On the contrary, vineyard and arable crops showed lower values. Soil POxC levels highlighted a similar trend to soil TOC in all land uses, showing greater percentage incidence in the upper soil layer than in the deep one. Therefore, POxC can represent a simple and reliable indicator, especially in the superficial soil layer, of land-use change and management practice effects on soil $\mathrm{C}$ stock, discriminating between easily degradable and recalcitrant soil $\mathrm{C}$ forms. With regard to the second and the third objectives of this study, a large number of interrelated factors govern soil $\mathrm{C}$ accumulation in Calabrian agroecosystems. Among these factors, the considered soil properties and climate variables exert a synergistic and significant effect on total and labile soil $\mathrm{C}$ stock. In particular, rainfall and temperature have a selective effect on soil $C$ distribution on the two sides of the Calabrian region, while among soil properties a prominent effect was observed from textural properties. In particular, if the Tyrrhenian side was characterized by higher TOC accumulation due to higher precipitation and colder temperature, the Ionic side of the region, on the contrary, revealed a lower accumulation of organic $C$ due to the higher temperatures and lower precipitation. Within this context, land use and soil properties compared to climatic variables might predict a lower amount of the variability of soil $C$ dynamics. Hence, it is relevant to investigate how climate change can affect soil $\mathrm{C}$ dynamics on the agricultural systems in Mediterranean areas. Further research is therefore needed to assess the effect of conservative practices in most common Calabrian agroecosystems, especially in those that show the lowest $C$ stock values, in order to increase soil organic $C$ concentration and contrast climate change.

Author Contributions: Conceptualization, M.M.; methodology, M.M. and A.G.; investigation, G.B., E.L.P. and M.R.; data curation, G.B.; writing-original draft preparation, G.B.; writing-review and editing, G.B., M.M., A.G. and E.L.P; supervision, M.M.; project administration, M.M. and A.G.; funding acquisition, M.M. and A.G. All authors have read and agreed to the published version of the manuscript.

Funding: This research was funded by the project "Modelli sostenibili e nuove tecnologie per la valorizzazione delle filiere vegetali mediterranee PON03PE_00090_3 Agrifoodnet".

Acknowledgments: We are grateful to Salvatore Gigliotti, Domenico Formica and Giuseppe Mastroianni for their help in soil sampling and samples preparation and to Beatrix Petrovičová for her technical advice.

Conflicts of Interest: The authors declare no conflict of interest.

\section{References}

1. Lal, R. Soil carbon sequestration to mitigate climate change. Geoderma 2004, 123, 1-22. [CrossRef]

2. FAO. International Year of Soil; FAO: Rome, Italy, 2015. 
3. Minasny, B.; Malone, B.P.; McBratney, A.B.; Angers, D.A.; Arrouays, D.; Chambers, A.; Chaplot, V.; Chen, Z.-S.S.; Cheng, K.; Das, B.S.; et al. Soil carbon 4 per mille. Geoderma 2017, 292, 59-86. [CrossRef]

4. Parras-Alcántara, L.; Díaz-Jaimes, L.; Lozano-García, B. Management effects on soil organic carbon stock in mediterranean open rangelands-treeless grasslands. L. Degrad. Dev. 2015, 26, 22-34. [CrossRef]

5. Liu, S.; Zhang, W.; Wang, K.; Pan, F.; Yang, S.; Shu, S. Factors controlling accumulation of soil organic carbon along vegetation succession in a typical karst region in Southwest China. Sci. Total Environ. 2015, 521-522, 52-58. [CrossRef]

6. Muñoz-Rojas, M.; Jordán, A.; Zavala, L.M.; De la Rosa, D.; Abd-Elmabod, S.K.; Anaya-Romero, M. Impact of Land Use and Land Cover Changes on Organic Carbon Stocks in Mediterranean Soils (1956-2007). L. Degrad. Dev. 2015, 26, 168-179. [CrossRef]

7. Averill, C.; Turner, B.L.; Finzi, A.C. Mycorrhiza-mediated competition between plants and decomposers drives soil carbon storage. Nature 2014, 505, 543-545. [CrossRef] [PubMed]

8. Francaviglia, R.; Benedetti, A.; Doro, L.; Madrau, S.; Ledda, L. Influence of land use on soil quality and stratification ratios under agro-silvo-pastoral Mediterranean management systems. Agric. Ecosyst. Environ. 2014, 183, 86-92. [CrossRef]

9. Marschner, B.; Brodowski, S.; Dreves, A.; Gleixner, G.; Gude, A.; Grootes, P.M.; Hamer, U.; Heim, A.; Jandl, G.; Ji, R.; et al. How relevant is recalcitrance for the stabilization of organic matter in soils? J. Plant Nutr. Soil Sci. 2008, 171, 91-110. [CrossRef]

10. Muñoz-Rojas, M.; Jordán, A.; Zavala, L.M.; De la Rosa, D.; Abd-Elmabod, S.K.; Anaya-Romero, M. Organic carbon stocks in Mediterranean soil types under different land uses (Southern Spain). Solid Earth 2012, 3, 375-386. [CrossRef]

11. Zdruli, P.; Jones, R.J.A.; Montanarella, L. Organic Matter in the Soils of Southern Europe; Office for Official Publications of the European Communities: Luxembourg, 2004.

12. IPCC Climate change 2007: The physical science basis. Intergov. Panel Clim. Chang. 2007, 446, 727-728.

13. Wang, Z.P.; Han, X.G.; Chang, S.X.; Wang, B.; Yu, Q.; Hou, L.Y.; Li, L.H. Soil organic and inorganic carbon contents under various land uses across a transect of continental steppes in Inner Mongolia. Catena 2013, 109, 110-117. [CrossRef]

14. Lal, R.; Kimble, J.M. Pedogenic carbonates and the global carbon cycle. In Global Climate Change Pedogenic Carbonates; CRC Lewis: Boca Raton, FL, USA, 2000; pp. 1-14.

15. Yaalon, D.H. Soils in the Mediterranean region: What makes them different? Catena 1997, 28, 157-169. [CrossRef]

16. Escolano, J.J.; Pedreño, J.N.; Lucas, I.G.; Almendro Candel, M.B.; Zorpas, A.A. Decreased organic carbon associated with land management in Mediterranean environments. In Soil Management Climate Change; Elsevier: Amsterdam, The Netherlands, 2018; pp. 1-13.

17. Bhattacharjya, S.; Bhaduri, D.; Chauhan, S.; Chandra, R.; Raverkar, K.P.P.; Pareek, N. Comparative evaluation of three contrasting land use systems for soil carbon, microbial and biochemical indicators in North-Western Himalaya. Ecol. Eng. 2017, 103, 21-30. [CrossRef]

18. da Silva Oliveira, D.M.; Paustian, K.; Cotrufo, M.F.; Fiallos, A.R.; Cerqueira, A.G.; Cerri, C.E.P. Assessing labile organic carbon in soils undergoing land use change in Brazil: A comparison of approaches. Ecol. Indic. 2017, 72, 411-419. [CrossRef]

19. ISTAT. 6 Censimento Generale Dell' Agricoltura in Calabria; ISTAT: Roma, Italy, 2012.

20. Iaquinta, P.; Terranova, O. Lineamenti climatici e termometrici della Calabria: Classificazione climatica di Köppen mediante sistemi GIS e Geoprocessing. In Relazione Finale "Pericolosità Legata ai Fenomeni di Intensa Erosione Idrica Areale e Lineare"; Terranova, O., Ed.; CNR IRPI: Cosenza, Italy, 2010; pp. 1-18.

21. Soil Survey Staff Soil Taxonomy: A basic system of soil classification for making and interpreting soil surveys. In Natural Resources Conservation Service, Agriculture; USDA: Washington, DC, USA, 1999.

22. ARSSA. I Suoli Della Calabria-Carta dei Suoli in Scala 1:250.000; Rubbettino Industrie Grafiche: Catanzaro Italy, 2003.

23. Grossman, R.B.; Reinsch, T.G. Core method. In Methods of Soil Analysis. Part 4 Physical Methods; Topp, G.C., Dane, J.H., Eds.; Soil Science Society of America Inc.: Madison, WI, USA, 2002; Volume 4, pp. 207-210.

24. Sparks, D.L.; Page, A.L.; Helmke, P.A.; Loeppert, R.H.; Soltanpour, P.N.; Tabatabai, M.A.; Johnston, C.T.; Sumner, M.E. Methods of Soil Analysis, Part 3. Chemical Methods; Soil Science Society of America Inc.: Madison, WI, USA, 1996; pp. 1085-1121. 
25. Weil, R.R.; Islam, K.R.; Stine, M.A.; Gruver, J.B.; Samson-Liebig, S.E. Estimating active carbon for soil quality assessment: A simplified method for laboratory and field use. Am. J. Altern. Agric. 2003, 18, 3-17.

26. Culman, S.W.; Snapp, S.S.; Freeman, M.A.; Schipanski, M.E.; Beniston, J.; Lal, R.; Drinkwater, L.E.; Franzluebbers, A.J.; Glover, J.D.; Grandy, A.S.; et al. Permanganate oxidizable carbon reflects a processed soil fraction that is sensitive to management. Soil Sci. Soc. Am. J. 2012, 76, 494. [CrossRef]

27. Benbi, D.K.; Brar, K.; Toor, A.S.; Singh, P. Total and labile pools of soil organic carbon in cultivated and undisturbed soils in northern India. Geoderma 2015, 237-238, 149-158. [CrossRef]

28. Walling, D.E.; Collins, A.L. Integrated Assessment of Catchment Suspended Sediment Budgets: A Technical Manual; University of Exeter: Exeter, UK, 2000.

29. Rittl, T.F.; Oliveira, D.; Cerri, C.E.P. Soil carbon stock changes under different land uses in the Amazon. Geoderma Reg. 2017, 10, 138-143. [CrossRef]

30. Hijmans, R.J.; Cameron, S.E.; Parra, J.L.; Jones, P.G.; Jarvis, A. Very high resolution interpolated climate surfaces for global land areas. Int. J. Climatol. 2005, 25, 1965-1978. [CrossRef]

31. Zomer, R.J.; Bossio, D.A.; Trabucco, A.; Yuanjie, L.; Gupta, D.C.; Singh, V.P. Trees and Water: Smallholder Agroforestry on Irrigated Lands in Northern India; IWMI: Colombo, Sri Lanka, 2007; Volume 122, ISBN 9290906855.

32. Zomer, R.J.; Trabucco, A.; Bossio, D.A. Climate change mitigation: A spatial analysis of global land suitability for clean development mechanism afforestation and reforestation. Agric. Ecosyst. Environ. 2008, 126, 67-80. [CrossRef]

33. SAS. SAS/STAT 9.3 User's Guide; User's Guid; SAS Inst. Inc.: Cary, NC, USA, 2011.

34. $R$ Team R: A Language and Environment for Statistical Computing; R Foundation for Statistical Computing: Vienna, Austria, 2013.

35. Lê, S.; Josse, J.; Husson, F. FactoMineR: An R package for multivariate analysis. J. Stat. Softw. 2008, 25, 1-18. [CrossRef]

36. Oksanen, J.; Blanchet, F.G.; Friendly, M.; Kindt, R.; Legendre, P.; McGlinn, D.; Minchin, P.R.; O'Hara, R.B.; Simpson, G.L.; Solymos, P. Vegan: Community Ecology Package. R Package Version 2.5-2, 2018.

37. Chiti, T.; Gardin, L.; Perugini, L.; Quaratino, R.; Vaccari, F.P.; Miglietta, F.; Valentini, R. Soil organic carbon stock assessment for the different cropland land uses in Italy. Biol. Fertil. Soils 2012, 48, 9-17. [CrossRef]

38. Chiti, T.; Blasi, E.; Pellis, G.; Perugini, L.; Chiriacò, M.V.; Valentini, R. Soil organic carbon pool's contribution to climate change mitigation on marginal land of a Mediterranean montane area in Italy. J. Environ. Manag. 2018, 218, 593-601. [CrossRef] [PubMed]

39. Willaarts, B.A.; Oyonarte, C.; Muñoz-Rojas, M.; Ibáñez, J.J.; Aguilera, P.A. Environmental factors controlling soil organic carbon stocks in two contrasting mediterranean climatic areas of southern Spain. L. Degrad. Dev. 2016, 27, 603-611. [CrossRef]

40. Farina, R.; Marchetti, A.; Francaviglia, R.; Napoli, R.; Di Bene, C.; Bene, C. Di Modeling regional soil C stocks and $\mathrm{CO}_{2}$ emissions under Mediterranean cropping systems and soil types. Agric. Ecosyst. Environ. 2017, 238, 128-141. [CrossRef]

41. Francaviglia, R.; Renzi, G.; Doro, L.; Parras-Alcántara, L.; Lozano-García, B.; Ledda, L. Soil sampling approaches in Mediterranean agro-ecosystems. Influence on soil organic carbon stocks. Catena 2017, 158, 113-120. [CrossRef]

42. Francaviglia, R.; Renzi, G.; Ledda, L.; Benedetti, A. Organic carbon pools and soil biological fertility are affected by land use intensity in Mediterranean ecosystems of Sardinia, Italy. Sci. Total Environ. 2017, 599-600, 789-796. [CrossRef]

43. Dixon, R.K.; Solomon, A.M.; Brown, S.; Houghton, R.A.; Trexier, M.C.; Wisniewski, J. Carbon pools and flux of global forest ecosystems. Science 1994, 263, 185-190. [CrossRef]

44. Novara, A.; La Mantia, T.; Barbera, V.; Gristina, L. Paired-site approach for studying soil organic carbon dynamics in a Mediterranean semiarid environment. Catena 2012, 89, 1-7. [CrossRef]

45. Muñoz-Rojas, M.; Abd-Elmabod, S.K.; Zavala, L.M.; De la Rosa, D.; Jordán, A. Climate change impacts on soil organic carbon stocks of Mediterranean agricultural areas: A case study in Northern Egypt. Agric. Ecosyst. Environ. 2017, 238, 142-152. [CrossRef]

46. Martin, M.P.; Wattenbach, M.; Smith, P.; Meersmans, J.; Jolivet, C.; Boulonne, L.; Arrouays, D. Spatial distribution of soil organic carbon stocks in France. Biogeosciences 2011, 8, 1053-1065. [CrossRef] 
47. Meersmans, J.; Martin, M.P.; De Ridder, F.; Lacarce, E.; Wetterlind, J.; De Baets, S.; Le Bas, C.; Louis, B.P.; Orton, T.G.; Bispo, A.; et al. A novel soil organic C model using climate, soil type and management data at the national scale in France. Agron. Sustain. Dev. 2012, 32, 873-888. [CrossRef]

48. Rodríguez-Murillo, J.C. Organic carbon content under different types of land use and soil in peninsular Spain. Biol. Fertil. Soils 2001, 33, 53-61. [CrossRef]

49. Mudge, P.L.; Kelliher, F.M.; Knight, T.L.; O'Connell, D.; Fraser, S.; Schipper, L.A. Irrigating grazed pasture decreases soil carbon and nitrogen stocks. Glob. Chang. Biol. 2017, 23, 945-954. [CrossRef] [PubMed]

50. Alberti, G.; Leronni, V.; Piazzi, M.; Petrella, F.; Mairota, P.; Peressotti, A.; Piussi, P.; Valentini, R.; Gristina, L.; La Mantia, T.; et al. Impact of woody encroachment on soil organic carbon and nitrogen in abandoned agricultural lands along a rainfall gradient in Italy. Reg. Environ. Chang. 2011, 11, 917-924. [CrossRef]

51. Li, X.; Wang, Y.; Liu, L.; Luo, G.; Li, Y.; Chen, X. Effect of land use history and pattern on soil carbon storage in arid region of central asia. PLOS ONE 2013, 8, e68372. [CrossRef]

52. Haynes, R.J. Labile organic matter fractions as central components of the quality of agricultural soils: An overview. Adv. Agron. 2005, 85, 221-268.

53. Wang, T.; Kang, F.; Cheng, X.; Han, H.; Ji, W. Soil organic carbon and total nitrogen stocks under different land uses in a hilly ecological restoration area of North China. Soil Tillage Res. 2016, 163, 176-184. [CrossRef]

54. Tortorella, D.; Gelsomino, A. Influence of compost amendment and maize root system on soil $\mathrm{CO}_{2}$ efflux: A mesocosm approach. Agrochimica 2011, 55, 161-177.

55. Badagliacca, G.; Benítez, E.; Amato, G.; Badalucco, L.; Giambalvo, D.; Laudicina, V.A.; Ruisi, P. Long-term effects of contrasting tillage on soil organic carbon, nitrous oxide and ammonia emissions in a Mediterranean Vertisol under different crop sequences. Sci. Total Environ. 2018, 619-620, 18-27. [CrossRef]

56. Sun, Y.; Ma, J.; Sun, Y.; Xu, H.; Yang, Z.; Liu, S.; Jia, X.; Zheng, H. The effects of different water and nitrogen managements on yield and nitrogen use efficiency in hybrid rice of China. F. Crops Res. 2012, 127, 85-98. [CrossRef]

57. Wu, H.B.; Guo, Z.T.; Peng, C.H. Changes in terrestrial carbon storage with global climate changes since the last interglacial. Quat. Sci. 2001, 21, 366-1373.

58. Tan, W.F.; Zhang, R.; Cao, H.; Huang, C.Q.; Yang, Q.K.; Wang, M.; Koopal, L.K. Soil inorganic carbon stock under different soil types and land uses on the Loess Plateau region of China. Catena 2014, 121, 22-30. [CrossRef]

59. Hurisso, T.T.; Culman, S.W.; Horwath, W.R.; Wade, J.; Cass, D.; Beniston, J.W.; Bowles, T.M.; Grandy, A.S.; Franzluebbers, A.J.; Schipanski, M.E.; et al. Comparison of permanganate-oxidizable carbon and mineralizable carbon for assessment of organic matter stabilization and mineralization. Soil Sci. Soc. Am. J. 2016, 80, 1352-1364. [CrossRef]

60. Srivastava, P.; Sharma, Y.K.; Singh, N. Soil carbon sequestration potential of Jatropha curcas L. growing in varying soil conditions. Ecol. Eng. 2014, 68, 155-166. [CrossRef]

61. Laudicina, V.A.; Palazzolo, E.; Catania, P.; Vallone, M.; García, A.D.; Badalucco, L. Soil quality indicators as affected by shallow tillage in a vineyard grown in a semiarid Mediterranean environment. L. Degrad. Dev. 2017, 28, 1038-1046. [CrossRef]

62. Hiederer, R. Distribution of Organic Carbon in Soil Profile Data; Office for Official Publications of the European Communities: Luxembourg, 2009; 126p.

63. Badagliacca, G.; Benítez, E.; Amato, G.; Badalucco, L.; Giambalvo, D.; Laudicina, V.A.; Ruisi, P. Long-term no-tillage application increases soil organic carbon, nitrous oxide emissions and faba bean (Vicia faba L.) yields under rain-fed Mediterranean conditions. Sci. Total Environ. 2018, 639, 350-359. [CrossRef]

64. Jobbagy, E.G.; Jackson, R.B. The vertical distribution of soil organic carbon and its relation to climate and vegetation. Ecol. Appl. 2000, 10, 423-436. [CrossRef]

65. Parras-Alcántara, L.; Lozano-García, B. Conventional tillage versus organic farming in relation to soil organic carbon stock in olive groves in Mediterranean rangelands (southern Spain). Solid Earth 2014, 5, $299-311$. [CrossRef]

66. Franzluebbers, A. Soil organic matter stratification ratio as an indicator of soil quality. Soil Tillage Res. 2002, 66, 95-106. [CrossRef]

67. Zhao, X.; Xue, J.F.; Zhang, X.Q.; Kong, F.L.; Chen, F.; Lal, R.; Zhang, H.L. stratification and storage of soil organic carbon and nitrogen as affected by tillage practices in the North China plain. PLoS ONE 2015, 10, e0128873. [CrossRef] [PubMed] 
68. Gelsomino, A.; Azzellino, A. Multivariate analysis of soils: Microbial biomass, metabolic activity, and bacterial-community structure and their relationships with soil depth and type. J. Plant Nutr. Soil Sci. 2011, 174, 381-394. [CrossRef]

69. Alvarez, R. Predicting average regional yield and production of wheat in the Argentine Pampas by an artificial neural network approach. Eur. J. Agron. 2009, 30, 70-77. [CrossRef]

70. Kiem, R.; Knicker, H.; Kögel-Knabner, I. Refractory organic carbon in particle-size fractions of arable soils I: Distribution of refractory carbon between the size fractions. Org. Geochem. 2002, 33, 1683-1697. [CrossRef]

71. Conforti, M.; Lucà, F.; Scarciglia, F.; Matteucci, G.; Buttafuoco, G. Soil carbon stock in relation to soil properties and landscape position in a forest ecosystem of southern Italy (Calabria region). Catena 2016, 144, 23-33. [CrossRef]

72. Tonon, G.; Sohi, S.; Francioso, O.; Ferrari, E.; Montecchio, D.; Gioacchini, P.; Ciavatta, C.; Panzacchi, P.; Powlson, D. Effect of soil $\mathrm{pH}$ on the chemical composition of organic matter in physically separated soil fractions in two broadleaf woodland sites at Rothamsted, UK. Eur. J. Soil Sci. 2010, 61, 970-979. [CrossRef]

73. Griffiths, R.I.; Thomson, B.C.; Plassart, P.; Gweon, H.S.; Stone, D.; Creamer, R.E.; Bailey, M.J. Mapping and validating predictions of soil bacterial biodiversity using European and national scale datasets. Appl. Soil Ecol. 2016, 97, 61-68. [CrossRef]

74. Kemmitt, S.J.; Wright, D.; Goulding, K.W.T.; Jones, D.L. pH regulation of carbon and nitrogen dynamics in two agricultural soils. Soil Biol. Biochem. 2006, 38, 898-911. [CrossRef]

75. Hu, P.L.; Liu, S.J.; Ye, Y.Y.; Zhang, W.; Wang, K.L.; Su, Y.R. Effects of environmental factors on soil organic carbon under natural or managed vegetation restoration. L. Degrad. Dev. 2018, 29, 387-397. [CrossRef]

76. Deng, L.; Zhu, G.-y.; Tang, Z.-s.; Shangguan, Z.-p. Global patterns of the effects of land-use changes on soil carbon stocks. Glob. Ecol. Conserv. 2016, 5, 127-138. [CrossRef]

77. Del Grosso, S.; Parton, W.; Stohlgren, T.; Zheng, D.; Bachelet, D.; Prince, S.; Hibbard, K.; Olson, R. Global potential net primary production predicted from vegetation class, precipitation, and temperature. Ecology 2008, 89, 2117-2126. [CrossRef] [PubMed]

78. Knorr, W.; Prentice, I.C.; House, J.I.; Holland, E.A. Long-term sensitivity of soil carbon turnover to warming. Nature 2005, 433, 298-301. [CrossRef] [PubMed]

79. Luo, Y.; Wan, S.; Hui, D.; Wallace, L.L. Acclimatization of soil respiration to warming in a tall grass prairie. Nature 2001, 413, 622-625. [CrossRef] [PubMed]

80. Delgado-Baquerizo, M.; Maestre, F.T.; Gallardo, A.; Bowker, M.A.; Wallenstein, M.D.; Quero, J.L.; Ochoa, V.; Gozalo, B.; García-Gómez, M.; Soliveres, S.; et al. Decoupling of soil nutrient cycles as a function of aridity in global drylands. Nature 2013, 502, 672-676. [CrossRef] [PubMed]

81. Rial, M.; Martínez Cortizas, A.; Rodríguez-Lado, L. Understanding the spatial distribution of factors controlling topsoil organic carbon content in European soils. Sci. Total Environ. 2017, 609, 1411-1422. [CrossRef]

82. Terranova, O.G. Caratteristiche degli eventi pluviometrici a scala giornaliera. In Proceedings of the XXIX Convegno di Idraulica e Costruzioni Idrauliche, Trento, Italy, 7-10 September 2004; EdiBios: Cosenza, Italy, 2004.

83. Ciais, P.; Wattenbach, M.; Vuichard, N.; Smith, P.C.; Piao, S.L.; Don, A.; Luyssaert, S.; Janssens, I.A.; Bondeau, A.; Dechow, R.; et al. The European carbon balance. Part 2: Croplands. Glob. Chang. Biol. 2010, 16, 1409-1428. [CrossRef]

84. Wagai, R.; Mayer, L.M.; Kitayama, K.; Knicker, H. Climate and parent material controls on organic matter storage in surface soils: A three-pool, density-separation approach. Geoderma 2008, 147, 23-33. [CrossRef]

85. Versace, P.; Ferrari, E.; Gabriele, S.; Rossi, F. Valutazione Delle Piene in Calabria; CNR IRPI: Cosenza, Italy, 1989.

86. Capra, A.; Consoli, S.; Scicolone, B. Long-term climatic variability in calabria and effects on drought and agrometeorological parameters. Water Resour. Manag. 2013, 27, 601-617. [CrossRef]

87. Rabbi, S.M.F.; Tighe, M.; Cowie, A.; Wilson, B.R.; Schwenke, G.; Mcleod, M.; Badgery, W.; Baldock, J. The relationships between land uses, soil management practices, and soil carbon fractions in South Eastern Australia. Agric. Ecosyst. Environ. 2014, 197, 41-52. [CrossRef]

(C) 2020 by the authors. Licensee MDPI, Basel, Switzerland. This article is an open access article distributed under the terms and conditions of the Creative Commons Attribution (CC BY) license (http://creativecommons.org/licenses/by/4.0/). 